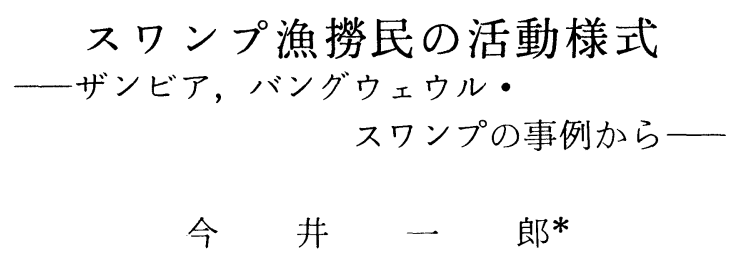

\title{
The Activity Patterns for living of the Fishermen in the Bangweulu Swamps, Zambia.
}

\author{
Ichiro Imai**
}

The aim of this paper is to describe and characterize the swamp fishing in the Bangweulu Swamps, Zambia, and contrast it with other human activities for livelihood such as hunting, gathering, pastoralism and agriculture.

The swamp fishermen migrate to the swamps from their home villages outside the swamps in the dry season when the water level decreases. They choose their camping site in the swamps and make a temporary hut. The fishermen in a camp form nsanga, the production unit for fishing and selling their catch, which is formed through their kinship relationships.

The fish catch by the several commercial fishing methods are analysed after the fishing methods are outlined. As a result of the analysis, it is indicated that each production unit aims to catch a particular group of fish, such as Mormyridae or Cichlidae fish, and each unit chooses a fishing method by which the target fish can be caught effectively.

The types of fishing activity among the fishermen are divided into three classes in terms of their fishing seasons and methods, and it is clarified how the swamp area is utilized actually by the several ethnic groups from different areas. These three types of fishing differ from each other as to how far their villages are from the swamps and what time schedule of agriculture is made which limits the season or the period of fishing in the swamps. The fishermen of the Bangweulu Swamps are engaged in the swamp fishing for themselves in spite of the fact they depend upon the products from their cultivation in their subsistence economy.

In the last part of this paper, it is discussed why the fishermen carry on fishing for themselves without making symbiotic relationships with other fishing specialists. They can get a good cash income by selling the catch, which urge them on fishing, and the fish meat offers much appeal to them, for they do not have a lot of domestic animals, nor can so many animals be hunted around their home villages. Thus, it is concluded that the both subsistence activities, cultivation and fishing, are essential to the life of the swamp fishermen in the Bangweulu Swamps.

* 弘前大学人文学部

** Faculty of Humanities, Hirosaki University 
目次

I はじめに

II 調査地域の民族

III 自然環境

1. 地形, 気候

2. 植生, 動物相

IV 漁掞キャンプと活動組織

1. 漁撈キャンプ

2. 漁撈ユニット

$\mathrm{V}$ 漁法, 漁獲

VI 漁民の活動類型

VII 結論

謝辞

参考文献

\section{I はじめに}

従来, 人類進化を究極の主題として行なわれて きた，アフリカ地域の人間社会を対象にした生態 人類学的研究においては, 中央カラハリのサン(田 中, 1971，1980など）やザイール森林地帯のムブ ティ・ピグミー（原子, 1977, 丹野, 1977, 市川, 1982など）といった採集狩椫民，タンガニイカ湖 東岸に住むトングウェ（掛谷，1974など）などの 農耕民，そして北ケニアの遊牧民レンディーレ

（Sato，1980など）の生業その他の活動が取り上 げられてきた。漁撈民社会の調査, 研究も, タン ガニイカ湖畔やザイール河畔（端，1968, 安渓, 1982 など）で行なわれ，民族誌がまとめられてい るが，スワンプという水域を舞台にした漁撈活動 の研究には手がつけられていない。

本稿では, 狩猟・採集, 牧畜, 農耕といった, 人類が行なう他の生業形態との対比において，ス ワンプにおける漁掞活動の特性を描き出すととを 目的とする。調查地域は，ザンビア共和国のバン グウェウル・スワンプである。

ザンビアは周囲を陸地にとり囲まれた内陸国で あるが，国内にはチャンベシ (Chambeshi),ザン ベジ（Zambezi）などの大河川が流れ，バングウ エウル (Bangweulu) 湖, タンガニイカ（Tanga- nyika）湖をはじめとする魚類相の豊富な内水面 が，いくつも発達している。そてに棲息する魚類 は，住民の食生活中, 動物性食物として重要な位 置をしめ，以前から活発に利用されてきた。今日 でも，ザンビアの内水面漁業は，国民に重要な食 料資源を提供している。

ザンビア国内には数多くの内水面漁場があるが, その中で商業的にも重要とされる漁場は, 図 1 亿 示す 8 地域である（Fishery Statistics, 1977 )。

(1) バングウェウル (Bangweulu) 湖, スワンプ

(2) ムウェル・ワンティパ (Mweru-Wa-Ntipa) スワンプ

(3) ムウェル (Mweru) 湖

(4) ルアプラ (Luapula) 川

(5) タンガニイカ (Tanganyika) 湖

(6) ルカンガ (Lukanga) スワンプ

(7) カフェ (Kafue) 川

(8) カリバ (Kariba) 湖

これらの地域は, コッパーベルト (Copper belt) 州の諸都市や, 首都ルサカ（Lusaka）などの消費 地に漁獲を供給している。各漁場では水産局(Department of Fishery)などの政府機関を中心に， 内水面漁業発達のための研究が行なわれてきた。 従来の研究は, カリバ湖やカフエ川に棲息する魚 類の形態や生態を取り扱ったあのが大部分をしめ, 内水面漁掞に用いられる漁法之漁獲分析, そして 漁民の生活様式をとりあげた研究はきわめて少な い。カフエ川流域の 3 地区に拈ける商業用漁獲量 を各魚種について通年的に計量し，分析を加えた Everett( 1974 )の報告があるのみである。

ザンビア水産局の年次報告 (1977，p. 15)によ れば，バングウェウル水域からの漁獲量は，ザン ビア国内の総漁獲量の $24.4 \%$ \%めている。乙 こからの漁獲の大部分はスワンプで得られたもの である。他漁場におけるスワンプ漁撈による漁獲 を加えれば，スワンプからの漁獲の総量は，ザン ビア全土の漁獲量の $50 \%$ 近くにも達するであろう。 この数値からみてあ, この地域におけるスワンプ 漁掞の重要性はきわめて高いといえるのであるが, この問題は，以下に述べる若干のあのを除いて， ほとんど研究されててなかった。ザンビア以外の 


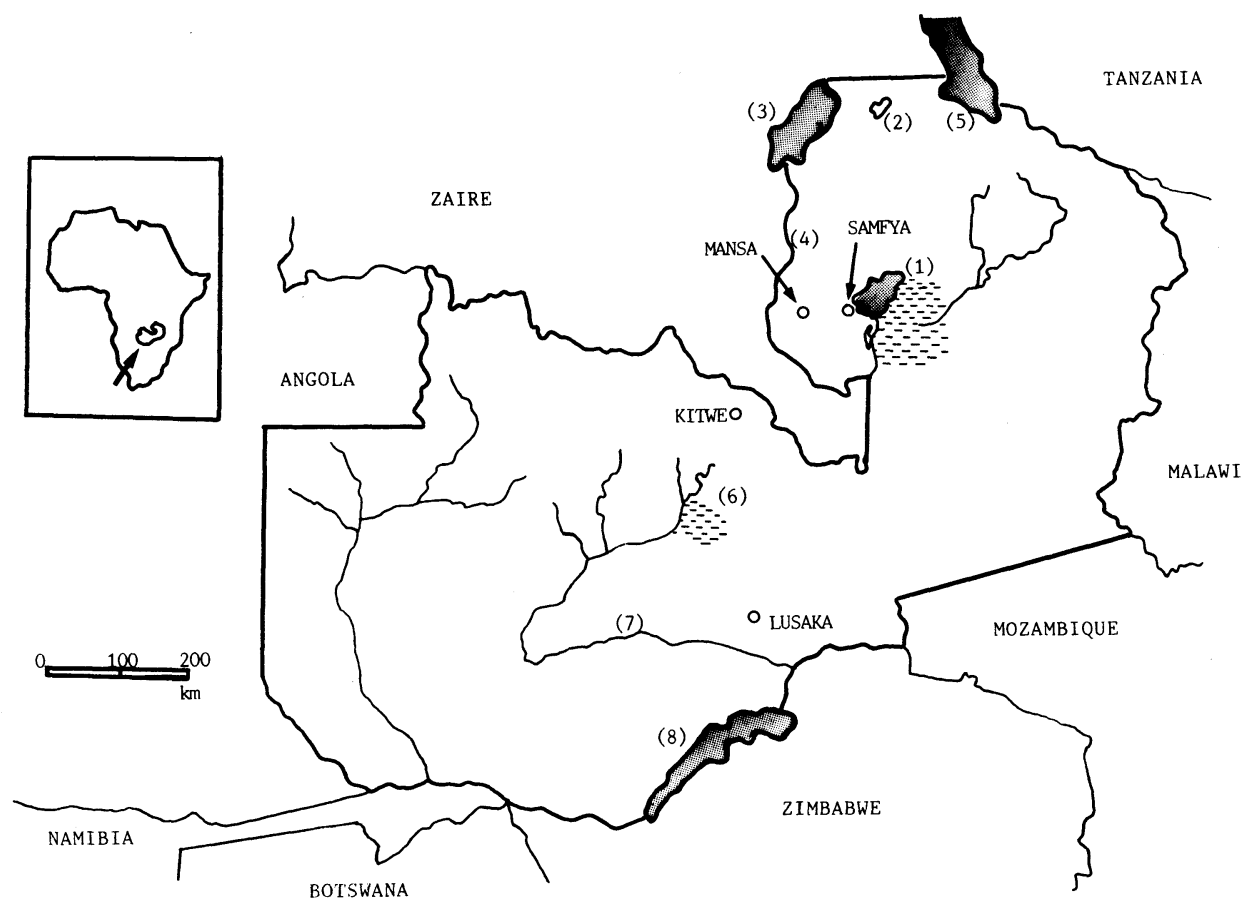

困1.ザンビア全困

国々におけるスワンプ漁撈についての調査報告も， また同様に欠如しているのである。

バングウェウル・スワンプの漁掞活動之漁民生 活を最初に研究したのは，W.V.Brelsford である。 彼は英領北ローデシア，ルウィング (Luwingu) 県の総督としてスワンプ内に運河を開削し(Brelsford,1944)，スワンプで漁撈を行なう諸民族につ いての貴重な報告（1946）を残した。彼は，スワ ンプ内に点在する島々に本村を持つウンガ(Unga) 族を対象に，スワンプ漁㗪の実態を浮かびあがら せ，通年的にあ経年的にあ大きく変動するスワン プの水位と人間生活の密接なかかわりを強調した。 また彼は，スワンプの自然環境や魚類の繁殖習性 にも注目しながら，スワンプを，魚類の繁殖域で はなく，採食域として位置づけた。そして，ウン ガがコッパーベルト州の都市や鉱山への出稼ぎよ りあスワンプ漁撈を指向する理由として，スワン プで漁撈活動に従事すれば，彼らは家族，親族内 の人間関係を維持しながら現金収入が得られる ことを指摘した。D.W.Evansは，バングウェウル
水産局の調査官として, バングウェウル湖西岸の 町サンフィヤ（Samfya）に駐在し，乙の水域の魚 類と個体群に関する基礎調査を行なって水産資 源の把握に努めた（Evans,1983）。その後，アフリ カのウッドランド帯の中でも特異な環境であるス ワンプにおける人間活動の生態人類学的研究の展 開を意図し，1982年に行なわれた掛谷誠ら(1983) の予供調査に引き続き, 1983年から, 市川光雄之 筆者がスワンプ漁掞に関する現地調査を開始した。 市川（Ichikawa,1985）は，6種の漁法による漁 獲内容を分析して，漁掞ユニットの採用する漁掞 戦略を， 1 漁法だけ選択して活動するスペシャリ ス卜戦略と, 同時に複数の漁法を採用するジェネ ラリスト戦略に分類した。そして，長期的にみれ ば各漁撈ユニット間の漁獲効率に顕著な差が見ら れないことを明らかにした。筆者(Imai,1985)は， スワンプ漁撈を全般的に記載する中で， 1 人の男 性を中心にして活動し，漁獲を売却して収益を分 け合う漁撈ユニット（nsanga）の存在を指摘した。 さらに，複数の民族集団からなる漁民の漁期，漁 
法などの面に見られる活動様式の差異を, 漁民間 の「すみわけ現象」としてとらえた。そして，他 の生業活動も含めて漁民生活を全体的に理解する ために, 漁民の本村に抢ける調査の必要性を指摘 した（前掲，p.55）。

筆者は 1 回目の調査(1983年9月～1984年1月)に 引き続いて，1985年 8 月から1986年 1 月にかけて, スワンプ内の島にあるウンガの本村と, 村の住民 が設置して活動する漁掞キャンプに滞在して 2 回 目の調査をおてなった。乙れにより, 漁民の本村 とその周辺で行なわれる漁撈以外の生業活動（農 耕など）をあ観察し，資料を得ることができた。

本稿ではまず，漁掞キャンプで繰り広げられる 活動の組織形態と漁法を記載し，主な漁法による 漁獲高を分析して相互に比較する。さらに, 漁民 によるスワンプの利用方式を分析して活動様式を 類型化し，それが産み出される要因を考察する。 そして，スワンプを含む人びとの生活領域全体の 中で，スワンプ漁撈が持つ意義に考察を進めたい。

\section{II 調查地域の民族}

バングウェウル湖は，ザンビア共和国ルアプラ

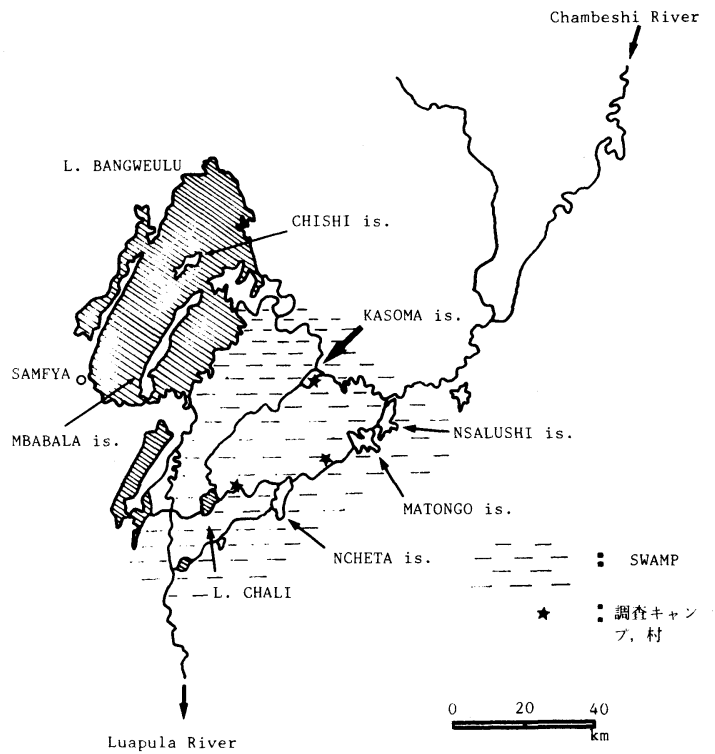

図 2. バングウェウル湖，スワンプ全図
州に属し, 総面積は 2,700 $\mathrm{km}^{2}$ 以上に達する（図 2 ）。 湖の西岸には, サンフィヤ県の県都サンフィヤが あり，地方行政の拠点になっている。湖の南東に は広大なスワンプが, 面積 $5,000 \mathrm{~km}$ 以上にわたっ てひろがり，そてではムババラ (Mbabala)、カソ マ（kasoma）、チェタ（Ncheta）などの湖やスワ ンプ内の島々，および湖周辺部に住む人びとが, 水位のさがる乾季（ 4 〜1月）飞漁掞活動をおこ なっている。彼らは，アシやパピルスなどからな る浮き島の上や，水路，ラグーンの岸に仮小屋を 建てて漁䈍キャンプを形成し，そこを基地にして 活動する。得た漁獲は煄製や日干魚に加工し，キ ャンプを訪れる商人に売却する。との地域一帯が, 現在のようにコッパーベルト州の都市を市場にし た漁業経済に組み入れられるようになったのは， 英領植民地時代からである。Brelsford（1946, p.79）によれば，コッパーベルト州への商業ルー トは 1924 年までにできあがった，という。その 当時のルアプラ川やバングウェウル湖周辺の住民 生活については，乙れまでにいくつかの報告が出 されている（Brelsford, 前掲, Cunnison,1959な ど)。

バングウェウル・スワンプで活動する漁民は， 湖の島や周辺の土地に居住するベンバ（Bemba） 語族の農耕民, グンボ (N'gumbo), ムクル ( $\mathrm{Mu}-$ kulu), カベンデ (Kabende), ビサ (Bisa) と, スワンプ内に点在する島々に住むウンガ(Unga) である（図 3 )。Brelsford（前掲, pp.11-15） によれば，乙れらの民族集団は 18 世紀にアンゴラ 方面から始まったベンバ族の移動に連動してての 地域に移住したというが，P.B.Mushindoは「ベン バ族小史」の中で（1977,p.XV), 彼らはこの地域 の先住民であった，と述べている。いずれにせよ， 彼らは文化的にベンバ族と近縁な民族である。1969 年に行なわれた政府の人口調査（Final Report, 1974 ）によれば，グンボの人口は約 40,000 人, カベンデが約 35,000 人，ウンガは約 16,000 人で あった。

スワンプ内のムボ (Mbo) 島や，ルアプラ河畔 のカンセンガ (Kansenga) などに居住する人びと の中には，漁撈を主生業とするバトゥワ（Batwa） 


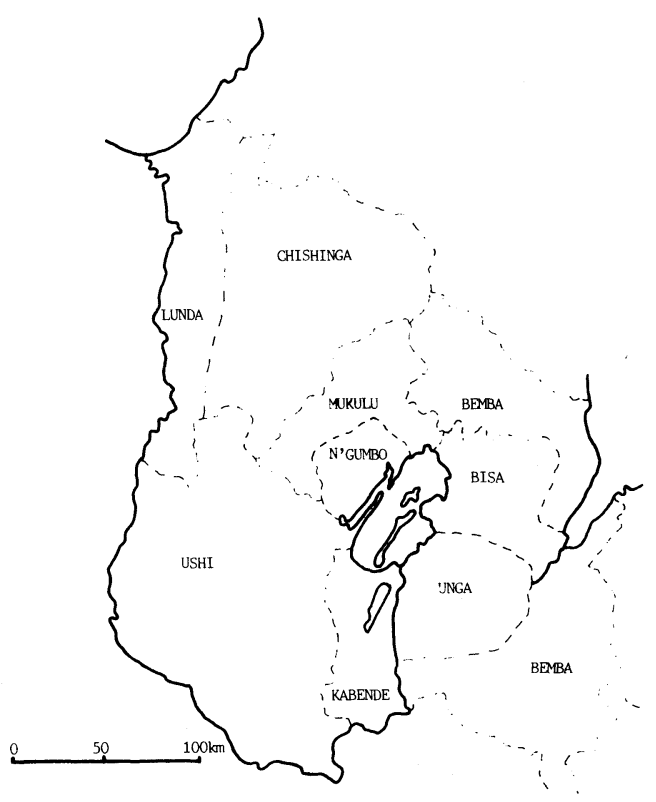

(G. Kay, 1962)

図 3. ルアプラ, バングウェウル地方の民族分布

と呼ばれる民族集団がいる，という。バトゥワは， 遣伝的にはブッシュマンとピグミーの中間形質を 保持しており，バンッ一族の到来とともに僻地へ 追いやられた民族 (Longworthy, 1971)だとされて いる。筆者の調査地域では, 2 回の調査を通じて トゥワ・グループを確認することはできなかった。 掛谷ら（前掲，pp. 43-44）あまた，ザンビアでは バングウェウルのほかにルカンガ・スワンプであ 広域調査をおこなったが，トゥワ・グループは見 、出せなかった。しかし, 筆者の調査地域の住民の 間では，専業漁撈民バトゥワの存在は広く信じら れており, 周辺の住民のように農耕を営むととが できず, 生活程度が低くて気性の激しい人間集団 として言及されている。バトゥワ自身はバトゥワ と呼ばれることを極度に嫌い，他の民族集団名（ウ ンガ，カベンデなど）を自称する，という。一般 にスワンプ住民を茂視する傾向は周囲の住民の間 に根強く, ウンガはスワンプの住民だからバトゥ ワと同様の存在とみなせる，と筆者に語ったグン ボのインフォーマントもいた。現時点では, トゥ ワ・グループは, 専業漁掞民として周囲の農耕民
から茂視されているが，その実在は確かめられて いない伝説的集団である，といえよう。

\section{III. 自然環境}

\section{1. 地形, 気候}

バングウェウル・スワンプの標高は約 $1,100 \mathrm{~m}$, 水深は 4〜 $5 \mathrm{~m}$ であり (Tait, 1965, p. 69), 平坦 で起伏の少ない島々が点在する。ザイール川の最 上流にわたるチャンベシ川をはじめ，いくつかの 河川がスワンプの北東から流入し, 南西部からは ルアプラ川が流出してムウェル湖に注ぐ。ての水 系の特徵として, スワンプに散在するラグーンを 結んで水路が開削され，人びとの交通路として広 く利用されていることああげられる。

Tait（前掲, p.69)によれば, バングウェウル 湖とスワンプの水質は $\mathrm{pH} 7$ 7゙, 貧栄養の状態であ る。乾季にはスワンプ域で酸素濃度が低下し, 鉄 分やリン酸塩を豊富に含んで赤褐色を呈する。魚 類はスワンプ内のよどみを嫌い，乙の時期は水面 の開けた湖へと移動していく。雨季が始まると, 降雨とそれにとあなうスワンプ域の浸水によって 水の成分が混合され，魚類は再びスワンプ域に増 加する。

Evans（前掲, p. 25) によれば, この地域は季 節的飞 1. 冷涼乾季 ( $5 \sim 8$ 月)，2. 温暖乾季 ( 8 〜 10月), 3 . 温暖雨季 (11〜 4 月) の 3 季に分け られる。冷涼乾季の平均気温は $16 \sim 17^{\circ} \mathrm{C}$ であり, 温暖乾季には $23 \sim 24^{\circ} \mathrm{C}$ まで上昇する。雨季の平均 気温は $21^{\circ} \mathrm{C}$ 前後である。年間降雨量は 1,300 1,400mm (Meteorological Department, 1971)で あり，降雨は11月から4月までの期間に集中する。 スワンプの水位は11，12月に最低になり，それ以 後は降雨とともに上昇する。 4,5 月頃には最高位 に達するが, 降雨日がほとんどなくなる 4 月中旬 から12月中旬にかけて水位は低下し続け，乙の期 間が漁民の活動期間になっている。1982年 7 月か ら 1983年6月にかけて, サンフィヤで記録された 降雨量とバングウェウル湖の水位を図 4 亿示す。 図に示されるように, バングウェウル湖の水位差 は年間約50インチ（約 $125 \mathrm{~cm} ）$ である。 


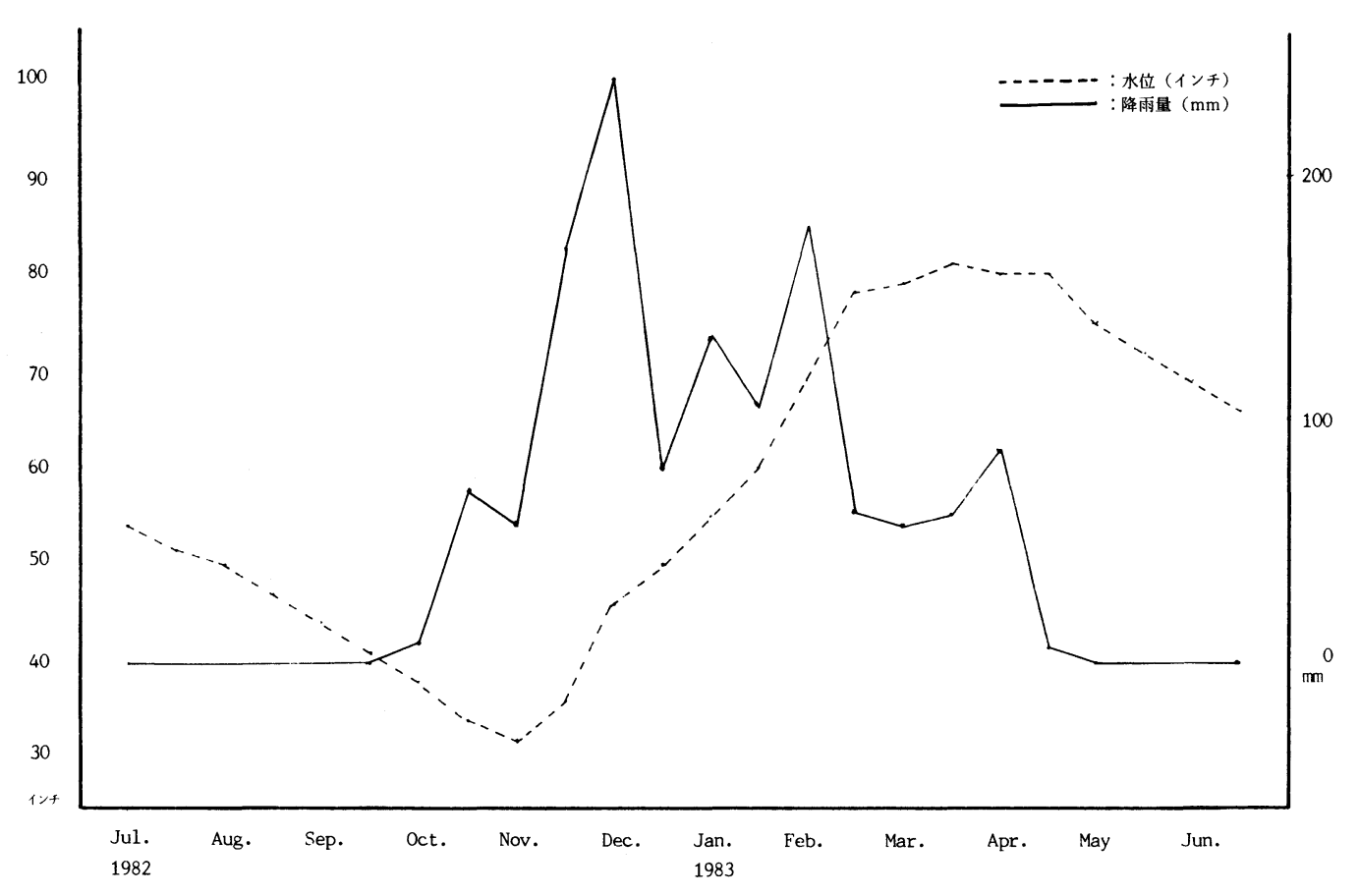

困 4. サンフィヤの降雨量と湖の水位

2. 植生, 動物相

調査地域一帯にはパピルス (Cyperus papyrus), ヨシ(Phragmites mauritianus)がおい茂り,島に 植えられたわずかなあのを除けば，樹木の生育は 見られない。水路やラグーンの水面には，スイレ ン(Nymphaea capensis)やハリイ (Eleocharis dulcis)などがみられる。また，人びとが以下に示 す 5 種の草本を漁撈キャンプ付近で採取して, 葉 菜として食用にするととを確認した。

Commelina buchanani (方名 icingongo)

Amaranthus dubius (ibondwe)

Ipomoea rubens (mulyamfubu)

Alternanthera nodiflora ( $n$ tenda)

Ocimum americana (lowena)

この水域では86種の魚類が記録されており，そ のうちの33種が商業的に重要な魚とされている (Tait, 前掲, p.69)。調査キャンプにおける記録に よれば，漁民は表 1 に示す33種の魚を捕獲し，乙 れらはすべて自家消費または売却されていた。魚 種の同定は, P.B.N. Jackson（1961 )のチェック
・リストを参照しながら，市川と筆者が行なった。 前述の通り, 魚類は水質の変化に応じてスワンプ 内を移動し, 多くの種は雨季に入ると産卵期をむ かえる。産卵期が年末に限られる種は数多い( Tait, 前掲, p. 70)。

この地域に棲息する動物の中では, ゾウ, レチ ュウェなどが乾季にスワンプ外縁の湿地帯に入り こむほか，水中にはカバが棲息している。漁民は スワンプで哺乳動物の狩诵を行なわないので，乙 れらの動物は人びとの生活にほとんど影響を与え ないが, カワウソやガン, カモ類によって, 定置 の刺網の漁獲が被害を受けることがよくある。鳥 類の捕獲を目的として，木綿の系を用いた簡単な 「くくり罠」(ubukusa)を, キ.ャンプ付近の水面上 に設置する漁民むいる。しかし，罠数は少なく獲 物が捕獲されることはまれであり, 積極的な狩猟 活動とはいい難い。

スワンプ全域の開水面（水路, ラグーン, 湖な ど）には多数のワニが棲息しており，漁民が漁撈 キャンプで襲われるととあある。 
表 1. 調査地域で確認された魚種と方名

\begin{tabular}{|c|c|}
\hline 学 & 方 名 \\
\hline \multicolumn{2}{|l|}{ MORMYRIDAE } \\
\hline Mormyrus longirostris Boulenger & mbubu \\
\hline Mormyrops deliciosus (Leach) & lombo \\
\hline Marcusenius monteirii (Gunther) & ncesu \\
\hline M. macrolepidotus (Peters) & mintesa \\
\hline Petrocephalus simus Sauvage & cise \\
\hline P. catostoma (Peters) & cipumamabwe \\
\hline \multicolumn{2}{|l|}{$C H A R A C I D A E$} \\
\hline Hydrocyon vittatus Castelnau & nsanga \\
\hline Alestes grandisquamis Boulenger & matula \\
\hline A. macropthalmus Gunther & manse \\
\hline A. imberi Peters & lusaku \\
\hline \multicolumn{2}{|l|}{ CITHARINIDAE } \\
\hline \multicolumn{2}{|l|}{$\begin{array}{l}\text { Distichodus maculatus Bouleng } \\
\text { CYPRINIDAE }\end{array}$} \\
\hline Barbus banguelensis Boulenger & mumbulwe \\
\hline Labeo altivelis Peters & mpumbu \\
\hline \multicolumn{2}{|l|}{ SCHILBERIDAE } \\
\hline Schilbe mystus (Linneaus) & lupata \\
\hline \multicolumn{2}{|l|}{$C L A R I D A E$} \\
\hline Clarias gariepinus Peters & umuta \\
\hline C. ngamensis Castelnau & umuta \\
\hline C. obscurus Poll & icimpule \\
\hline C. theodorae Weber & mulomfi \\
\hline C. buthpogon Sauvage & bomba \\
\hline \multicolumn{2}{|l|}{ Heterobranchus longifilis } \\
\hline Valanciennes & sampa \\
\hline \multicolumn{2}{|c|}{ MOCHOKIDAE } \\
\hline Synodontis ornatipinnis Boulenger & bongwe \\
\hline $\begin{array}{l}\text { S. nigromaculatus } \text { Boulenger } \\
B A G R I D A E\end{array}$ & cinnymba \\
\hline Chrysichthys mabusi Boulenger & kabonbola \\
\hline \multicolumn{2}{|c|}{ CICHLIDAE } \\
\hline \multicolumn{2}{|c|}{ Sarotherodon macrochir Boulenger nkamba } \\
\hline Tilapia rendalli Domeril & mpende \\
\hline T. sparmanii Smith & matuku \\
\hline \multicolumn{2}{|l|}{ Serranochromis angusticeps } \\
\hline S. robustus (Gunther) & nsuku \\
\hline S. thumbergi (Castelnau) & ntasa \\
\hline \multicolumn{2}{|l|}{ Haplochromis mellandi } \\
\hline $\begin{array}{l}\text { Tylochromis bangwelensis Regan } \\
A N A B A N T I D A E\end{array}$ & nsangula \\
\hline Ctenopoma multispinis Peters & nkomo \\
\hline
\end{tabular}

\section{IV 漁撈キャンプと活動組織}

前章（I）で触れたように，通年的にスワン プに滞在して漁撈に従事する漁民は存在しない。 $1 \sim 3$ 月には頻繁な降雨に見舞われて漁獲の乾燥 に支障をきたすだけでなく，多くのキャンプ地が 浸水し，乙の期間に漁民が活動するととは不可能 になる。彼らは，スワンプかバングウェウル湖の 島, 周囲の土地に本村をかまえ, キャッサバ, 卜 ウモロコシ，シコクビエなどを栽培し，その収穫 物によって生活している。農耕と漁撈が密接にか かわり合って, 彼らの生計を成り立たせているの である。したがって, 彼らの漁撈期間は農耕暦とス ワンプの水位に左右されるのであるが，乙の点は 後章（VI）で再び取り上げるととにする。

本章では，主として漁撈キャンプにおける活動 に注目しながら, 漁民が形成する漁撈組織につい て述へ，次章において，スワンプでおこなわれる 漁法を概観したのち，それぞれの漁法による漁獲 を分析する。

\section{1. 漁撈キャンプ}

漁民は，漁撈キャンプをpamitanda またはmitanda と呼ぶ。掛谷ら (Kakeya et. al., 1985, p. 12）によれば，ムピカ（Mpika）付近の農耕民べ ンバも, Citemene システムによるシコクビエ栽 培のための焼畑出作り小屋のととを, mitandaと 呼ぶ。

スワンプの中には乾季においてさえ陸地がそし く, その分布は水位の高低によって変化するので, 漁民が仮小屋を建造し，漁撈キャンプとして利用 できる地点は限られる。Brelsford（前掲, p.74） が述べるとおり，スワンプはすべての漁民に開放 されており, どの地域も自由に利用できる。した がって, 漁民はいくつかのキャンプ地の中から自 己の仮小屋を建てる場所が残されているキャンプ を選択して，その年の漁を行なうととになる。小 屋が浮き島の上に建てられることあある。

特定の個人や単一の民族集団に属する漁民が, 1 個の漁撈キャンプを占有して利用することはな いが，一般的には，同村や近隣村落に居住する友 
人や，相互に親族関係にある同じ民族集団に属す る者たちは，伝統的に特定のキャンプに集中して 活動する傾向がある。表 $2 \mathrm{a}, \mathrm{b}$ に示すとおり，筆 者の 1983 年の調査キャンプは, グンボ, ウンガ, カベンデ，1985年の調査キャンプは，ビサ，ウ ンガ，カベンデの漁民が利用しており，同じ民族 集団の漁民の間には，図 5 に示すような親族関係 が見られた。彼らの多くは，毎年同じキャンプを
利用して活動する，とのととだった。民族集団を 越えた姻戚関係む存在し, 彼らは後述する漁撈工 ニットを形成して，とあに活動する場合あある。 各漁掞キャンプは伝統的に，付近の島に住むウ ンガ首長に所属し，そこを利用する漁民は，首長 に魚または現金を入漁料として支払う慣習がある。 現在であ，首長の使者を自称する者が，入漁料を 取りたてに漁掞キャンプをまわることがあるが，

表 2. a 調査キャンプの漁撈ユニット, 漁法, 漁撈期間

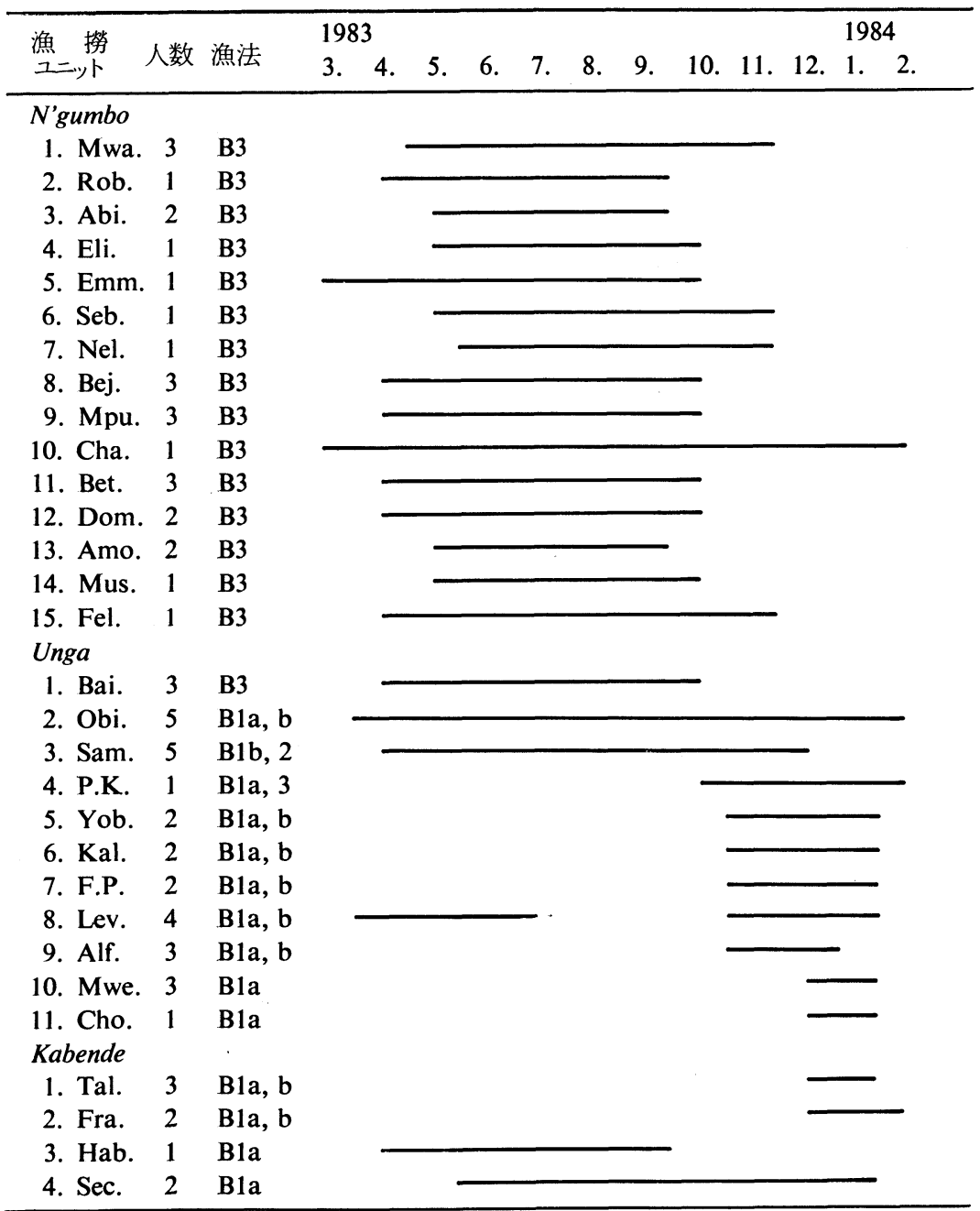

B1a: Malalikishya; B1b: Ukusebeshya; B2: Mukwao; B3: Mukombo;

A5: ubwamba; 一: 漁撈期間. 
表 $2 . b$ 調査キャンプの漁撈ユニット, 漁法, 漁撈期間

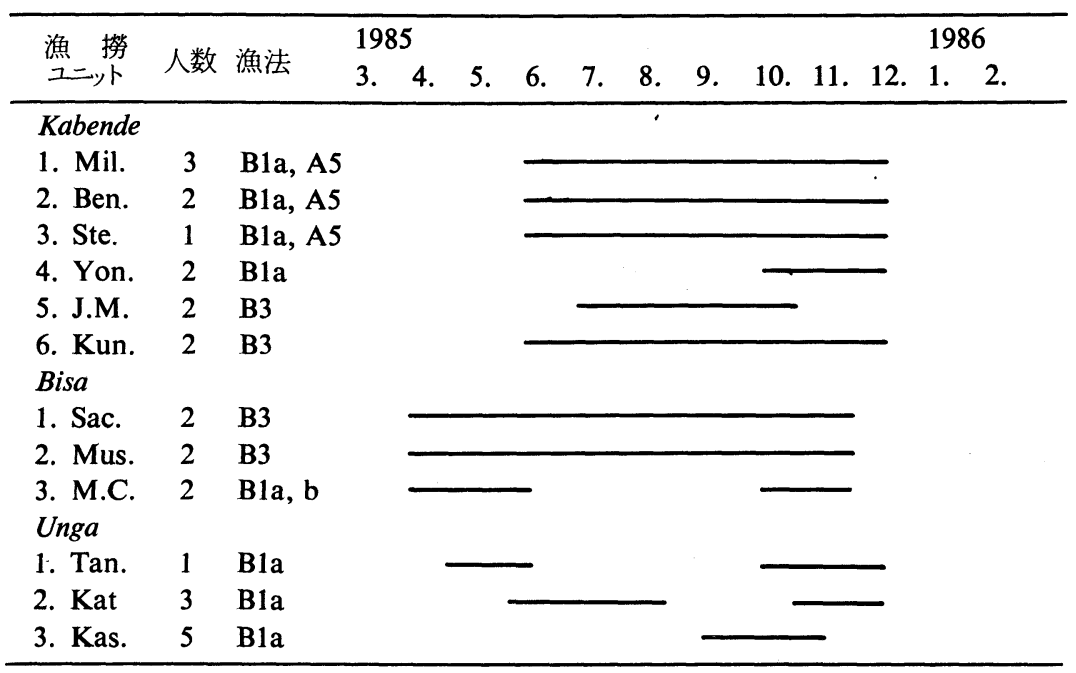

a.グンボ漁民
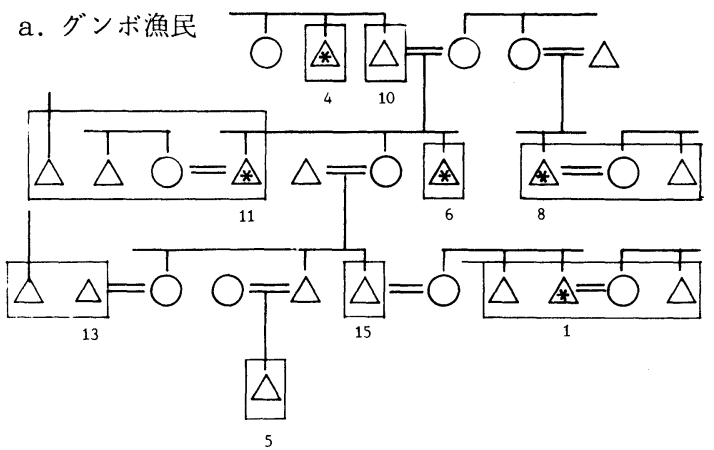

b. ウンガ漁民
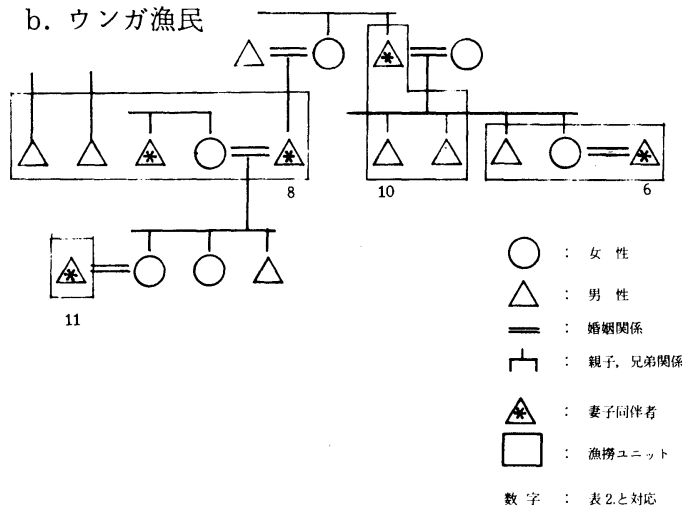

困 5. 調査キャンプ(1983年)の漁民の親族関係
実際には厳格に徴収されてはいない。

漁撈キャンプには，首長や固定的なメンバーは 存在せず，キャンプの漁民が 1 団となって活動す るわけでもない。また，近隣の異なるキャンプを 利用する漁民相互の結びつきも希薄である。しか し,トウモロコシの粉, シコクビエ, 砂糖やイー ストなどから醸造したアルコール性飲料 (ombwa, mandalakwaなど）を飲むために，漁民が漁を休 んでそれが製造されたキャンプを訪問することが よくある。

以上のように, 漁撈キャンプ内の漁民は全体と して機能的な集団とはみなせないが，個々のキャ ンプ成員は, 次に述べる漁撈ユニットのメンバー として活動しているのである。

\section{2. 漁撈ユニット}

漁民の間には，漁撈活動を協同して行ない，漁 獲を売却して得られた収益を成員間で分け合う漁 撈ユニットが形成される。この地域ではそれを， $n s a n g a$ と呼んでいる。Tait（前掲, p. 70) は, 1 人の漁民が数人の協力者を雇うことがよくある， と記しているが，乙こで述べる漁撈ユニットに冒 しては, Ichikawa（前掲，p. 31）と筆者（前掲，p. 57）によって報告されているだけである。nsanga 
とは，バングウェウル・スワンプにおける漁䈍活 動の単位であり, 漁獲売却の単位であある。漁撈 キャンプに滞在して単独で活動する漁民あみられ, その場合には単独であnsanga とみなされる。彼 は自らが漁掞活動を行なうだけでなく，独自に漁 獲を売却し，利益を得ることができるからである。 各漁撈ユニットは, 特定の漁法を選択して活動し, キャンプを訪れる商人に漁獲を売却するが，時に は代表者がコッパーベルト州の都市まで漁獲を運 んでいって売却する。

nsangaは, 1 人の男性 (umushila), 彼の協力 者 (umuswa), そして彼らの妻や子供たちから構 成されている。umushila とは, 漁具（漁網，力 ヌーなど）を所有し，かつスワンプで漁撈を行な うことのできる漁民をさす語である。すなわち， umushilaは漁撈資本と技術を兼的備えている。 ウンガのインフォーマントによれば, ウンガの人 びとの間では漁撈ュニットの長は umukolombeshi と呼ばれ, 彼が所有する漁掞資本（漁網, カヌー, 薪など）をnsanga と呼ぶ，という。漁獲を煄製に 加工して売却するnsangaの umushilaは, 漁獲の 燻製に用いる金網（wire）屯所有する。umuswa

（複，abaswa）は, 自己の漁具を所有せず, umushilaのnsanga（漁具，食料）に依存しながら漁 撈に従事する。umushilaは, abaswaの数に応じ て彼らとその家族が宿泊する仮小屋の材料を，漁 掞キャンプに用意して， abaswa とともに小屋を 建造する。彼らはキャンプで起居をとあにし, 漁 獲売却のために協力し合うのである。umushila とumuswaをまとめて, 漁掞ユニットととらえる ことができるが，漁民自身あそれを認識して，本 来は umushila の漁䈍資本を意味するnsanga と いう語で，漁掞ユニットを呼称するのである。と れが漁獲売却単位であることを強調し,"company” と呼ぶインフォーマントあいた。

umushila 之 umuswa の関係は永続的なあのでは なく, 普通は 1 漁期だけに限られる。グンボのイ ンフォーマントによれば，カヌーや漁網などの漁 具を所有し，食料や薪などを調達することができ る男性は，漁期の迫る 2 月頃になると，その年の 彼の umuswaを募る。それに応じて, 彼の umu- $s w a$ として活動したい者が，彼と話し合う。両者 が, 漁期間, 漁場や利益の配分率などの点で合意 すると, 彼らは同じnsangaの成員として, スワ ンプに向かう。同村の友人同士や，父子，兄弟が 同じnsanga の成員になる例も多いが，一般には， 互いに義兄弟（mulamo）の関係にある者たちが ユニットを形成する。umushilaの姉妹の夫，妻 の兄弟や，妻の姉妹の夫が, umuswa として彼の nsanga に加わることが多いのである。

漁獲売却によって得た利益の，ユニット成員へ の配分比はユニットごとに異なる。umushila は 漁撈資本を提供するので, 他の成員より多く配分 されるが，漁䈍技術を十分に習得していない，末 熟な umuswaへの配分率は低い。調査キャンプの あるユニット（abaswa5名）では, umushila が 利益の $30 \%$ を取得し，残金を abaswa 5 名で等分 する，とのととだった。スワンプで漁掞生活を始 めてから, 漁獲量が当初の予想を上回って高い利 益をあげた場合には，ユニットの umuswaが事前 に umushila と合意していた利益配分比に不満を 持ち，交渉をやり直すことあある。再交渉の結果， 両者の合意が得られない時には, ウンガの umu$s w a$ はュニットを離脱して帰村するが，グンボ 漁民は，漁期が終って帰村してからも交渉を継続 する。ウンガ漁民のユニットでは，商人に漁獲を 売却するたびに利益を分け合うが，グンボ漁民の ユニットでは，本村に戻ってから 1 漁期分まとめ て支給されるのが慣例になっているので，てのよ うな差異が生ずる，という。

以上のように, nsangaという漁䈍ュニットは, 漁獲の売却によって利益を得るととを前提に形成 されている。したがって，ての種の漁撈組織は， バングウェウル・スワンプが，現在のようにコッ パーベルト州の諸都市を市場にした漁業経済に組 み込まれるようになってから形成された，と推測 される。

しかし，バングウェウル・スワンプにおける漁 掞ユニット（nsanga）沈いては， umushila と umuswaの間に父子, 兄弟, 義兄弟などの親族関 係が存在し，両者が経済的関係を越えて結びつい ているととを指摘しておきたい。 
また，実際には漁䈍活動に参加することのほと んどない，ユニット成員の家族である乳奻児や女 性たちも漁撈キャンプで生活するてとが当然とさ れており，図 5 に示したように，妻子をともなっ てスワンプに滞在する漁民が多いととも，つけ加 えておかねばならない。

\section{V 漁法，漁獲}

Mortimer (1965, p. 33)によれば, ザンビアで おてなわれている内水面漁撈の漁法は, 次の 2 種 に大別できる。

A. 小規模漁法 (small-scale fishing method)

B. 営利漁法 (commercial fishing method)

前者は，漁民とその家族が自家消費用に行なう小 規模で伝統的な漁法であり, 後者は, 経済的利益 を目的とし，おむに漁網を用いて行なう漁法であ る。Evans（前掲，p.22）によれば, 1940年代に ナイロン製の漁網が導入され，1950年までに漁民 の間に普及した，という。現在では，国外から輸 入された漁網が，国産品のほかに数多く用いられ ている。調査キャンプのほとんどの漁民は，台湾， 中国製の漁網を使用している。網の規格は，全長 50 ヤード $($ 約 $45 \mathrm{~m})$, 深さは26メッシュで, メッシ ュサイズには約 $1 \mathrm{~cm}$ 以上何種類もある。村落内の 店舗でも購入できるが, 網をカヌーに載せて漁撈 キャンプを訪問し，漁民に販売する商人あいる。 定置の刺網漁を行なう漁民は，各自が漁網に浮子， 沈子を取り付けて網を 2 枚つなぎ，全長 100 ヤー ドに伸ばして用いる。Triumfetta cordifolia (mamina)の茎からは細長いタイプの浮子が製作 され，後述する kacaala 網の浮子に用いられる。 また, 漁民は水底から粘土質の泥を掘り出して焼 き固め, 沈子 (amabwe) とする。本章では，バ ングウェウル・スワンプで用いられている漁法を Mortimer（前掲）の分類にしたがって整理し, 営 利的漁撈のために広く採用されている漁法による 漁獲を分析し，その特徴を明らかにする。表 3 に, 漁法の一覧を示す。
表 3. バングウェウル・スワンプの漁法

\begin{tabular}{|c|c|}
\hline A. 小規 模 漁 法 (Small & scale fishing method) \\
\hline 1. 棹 釣 り & ndobani \\
\hline 2. 延 縄（浅水域） & a. mwando \\
\hline " ( 湖 ) & b. akabamba \\
\hline$" \quad$ （底延縄） & c. ubunyimba \\
\hline 3. 擬似 餌 法 & semu \\
\hline 4. 小魚の追い込み漁 & ukusaya \\
\hline 5. 筌 漁 & ubwamba \\
\hline 6. 槍 & imiela \\
\hline 7. 魚 毒 法 & ububa \\
\hline B. 営利 漁法 (Commer & cial fishing method) \\
\hline 1. 定置の刺網（ 1 晚） & a. malalikishya \\
\hline " (夜間の数時間) & b. ukusebeshya \\
\hline （数日間） & c. mutobi \\
\hline " （日中の数時間） & d. mapila \\
\hline 網（地曳網） & a. mukwao \\
\hline " （カヌー上） & b. kapopela \\
\hline 3. 追い込み漁 & mukombo \\
\hline 4. 流 し 網 & ukukunguluka \\
\hline
\end{tabular}

\section{A. 小規模漁法}

\section{A 1. 棹釣り ndobani}

日中に男たちが出漁している間，キャンプに残 された女性や子供たちが，キャンプの周囲で「お かずとり」として行なう釣漁である。付近の灌木 の枝を棹として用いるが，系釣りをすることも多 い。釣針の先端につける慨としては，人びとの主 食であるトウモロコシの粉の練り㐨（nshima） の残りや，キャンプ周辺で掘りだしたミミズ (ifyambo）などが用いられる。釣りによる漁獲種と しては, Alestes属の魚類であるA. macropthalmus (manse), A. imberi (lusaku) や, シク リッド科の Haplochromis mellandi ( mbilia), Serranochromis angusticeps (polwe), Tylochromis bangwelensis (nsangula) などが見られた。

\section{A 2. 延 縄 a. mwando b. akabamba} 水面に縄を張って幹縄とし, 幹縄からナイロン 系などを用いて水中に釣針を何本も下げて静置す る。水深の浅い水域 ( $1 \mathrm{~m}$ 未満) に設置される $m$ wando と，それより深い湖などに設置される $a k a-$ bamba がある。 
A 2 a. mwando

mwandoに用いる幹縄としては，市販のトウモ ロコシ秎の袋をほぐし，その化緎の系を撚り合せ て用いることが多い。枝縄の長さが約 $30 \mathrm{~cm}$ 釣針 を，約 $1 \mathrm{~m}$ の間隔で幹縄に付けて延縄とする。幹 縄の両端は, 水底に刺し込んで固定した長さ 1 $2 \mathrm{~m}$ の棒に結びつける。定置網漁で獲れたモルミ ルス科魚類の切身が, 慨として用いられる。ミミ ズや魚の内臟が用いられることあある。漁民は, 流れのない水域に延縄を設置し, 翌日点検して漁 獲を回収し，慨を交換する。延縄の点検と漁獲の 回収は数日間くり返され，捕獲率が低下してくる と, 延縄の設置水域を変える。延縄の長さによっ て釣針の総数は異なるが, 多くの場合 10〜 50本で ある。漁獲種には, Clarias属, Serranochromis 属の魚類が多いが, Hydrocyon vittatus(nsanga) あ頻繁に捕獲される。

\section{A 2 b. akabamba}

この漁法では, 水深の深いラグーンや湖など, 開けた水面に延縄が設置される。幹縄の全長は, $100 \mathrm{~m}$ 近くに達し, 釣針は小型で 200 本近く用い られる。一般に，早朝に設置して午後には点検す る。慨としては, 鱗翅目昆虫の幼虫 (umufunsu) などが用いられる。Auchenoglanis occidentalis (nsanga), Synodontis nigromaculatus (cinn$y m b a)$ などを捕獲目標とする。これは，スワン プ域に特有つ漁法とはいえないが, 調查地域内で は, 水深が深くて水面が開けているチャリ（chali）湖で行なわれることがあるという。

また，幹縄を湖底に設置するA 2 c. ubunyim$b a$ と呼ばれる延縄漁の存在む, 聞き込みの中で 漁民に指摘された。

\section{A 3. 擬似饂漁 semu}

調査地域では，市販されている擬似慨が用いら れる。乙れは漁民が余暇を利用して散発的に行な う程度だというが，筆者の調査キャンプでは観察 されなかった。
A 4. 小魚の追い込み漁 ukusaya この漁のために製作された籠（ulwanga），また

は漁民がトウモロコシ粉の袋から製作して利用す る蚊帳（candaluwa）を用いた小魚の追い込み漁 であり，女性や少年たちによってキャンプ付近の 浅瀬で行なわれる。調查キャンプでは, Alestes macropthalmus (manse) の幼魚 (tala), Barbus banguelensis (mumbulwe), Haplochromis mellandi ( mbilia) の幼魚の捕獲が観察さ れた。乙れらの小魚がキャンプ周囲の水域で目に つくようになる10〜12月に，「おかずとり」とし てよく行なわれる。魚群を発見すると， $1 \sim 2$ 人 でulwanga かcandaluwa を構え，他の数名が勢 子として上流から魚群を追い込むのである。表 4 には，筆者が 1985 年の調査中に記録したBarbus banguelensis を対象に行なわれた， 3 人の女 性による ulwanga への追い込み漁の 1 回の漁獲内 容を, 次に述べる鉒漁による漁獲内容とともに示 す。表からは，乙の魚が漁獲尾数中の $93 \%$, 漁獲 重量の $64.5 \%$ をめ, 小規模で偶発的に行なわれ る「扔かずとり」にもかかわらず，特定の魚種が 効率的に採捕されているととがわかる。

\section{A 5. 鉒 漁 $u b w a m b a$}

鉒と柵を併用する浅水期の漁法である。筌は $u$ mono（複,imyono），柵は ubwamba と呼ばれる。 水路内に, matete と呼ばれるョシ（phragmites mauritianus) の茎などで柵を築き, 水面下の 柵に筌を設置する。Brelsford（前掲，p.60）によ れば，スワンプ辺縁域では減水期に土塁を築いて $u b w a m b a$ とする。魚類は水流に乗り，上流部か ら筌に引き込まれて捕獲される。漁獲内容(表 4) から明らかなように，捕獲された魚はMarcusenius macrolepidotus (mintesa) に集中し, 漁獲 尾数中の $97 \%$, 重量む約 $91 \%$ しめる。Schilbe mystus (lupata) が大量に捕獲されることも ある，という。本稿ではこの漁法を小規模漁法と して分類したが, 営利漁法として採用し, 大規模 に行なう漁民も存在する。 
表 4. A4. 小魚の追い込み漁, A5. 鉒漁による漁獲例

\begin{tabular}{|c|c|c|c|c|}
\hline \multirow{2}{*}{ 魚種 } & \multicolumn{2}{|c|}{ ulwanga漁 } & \multicolumn{2}{|c|}{ ubwamba漁 } \\
\hline & 尾数 & 重量 $(k$ & g)尾数 & 重量 $(\mathrm{kg})$ \\
\hline \multicolumn{5}{|l|}{ Mormyrus longirostris Boulenger } \\
\hline \multicolumn{5}{|l|}{ Mormyrops deliciosus (Leach) } \\
\hline \multicolumn{5}{|l|}{ Marcusenius monteirii (Gunther) } \\
\hline M. macrolepidotus (Peters) & & & 389 & 15.7 \\
\hline \multicolumn{5}{|l|}{ Petrocephalus simus Sauvage } \\
\hline \multicolumn{5}{|l|}{ P. catostoma (Peters) } \\
\hline \multicolumn{5}{|l|}{ Hydrocyon vittatus Castelnau } \\
\hline Alestes grandisquamis Boulenger & 1 & & & \\
\hline \multicolumn{5}{|l|}{ A. macropthalmus Gunther } \\
\hline \multicolumn{5}{|l|}{ A. imberi Peters } \\
\hline \multicolumn{5}{|l|}{ Distichodus maculatus Boulenger } \\
\hline Barbus banguelensis Boulenger & 1,049 & 4.55 & 1 & \\
\hline \multicolumn{5}{|l|}{ Labeo altivelis Peters } \\
\hline Schilbe mystus (Linneaus) & & & 2 & \\
\hline \multicolumn{5}{|l|}{ Clarias gariepinus Peters } \\
\hline \multicolumn{5}{|l|}{ C. ngamensis Castelnau } \\
\hline \multicolumn{5}{|l|}{ C. obscurus Poll } \\
\hline C. theodorae Weber & & & 3 & \\
\hline \multicolumn{5}{|l|}{ C. buthpogon Sauvage } \\
\hline \multicolumn{5}{|l|}{ Heterobranchus longifilis Valanciennes } \\
\hline \multicolumn{5}{|l|}{ Synodontis ornatipinnis Boulenger } \\
\hline \multicolumn{5}{|l|}{ S. nigromaculatus Boulenger } \\
\hline \multicolumn{5}{|l|}{ Chrysichthys mabusi Boulenger } \\
\hline \multicolumn{5}{|l|}{ Auchenoglanis occidentalis C.\&V. } \\
\hline \multicolumn{5}{|l|}{ Sarotherodon macrochir Boulenger } \\
\hline Tilapia rendalli Domeril & 2 & & & \\
\hline T. sparmanii Smith & 60 & & 2 & \\
\hline Serranochromis angusticeps (Boulenger) & 7 & & 2 & \\
\hline \multicolumn{5}{|l|}{ S. robustus (Gunther) } \\
\hline S. thumbergi (Castelnau) & 1 & & 1 & \\
\hline Haplochromis mellandi (Boulenger) & 7 & & & \\
\hline Tylochromis bangwelensis Regan & & & 1 & \\
\hline \multicolumn{5}{|l|}{ Ctenopoma multispinis Peters } \\
\hline 総 漁 獲 量 & 1,127 & 7.05 & 401 & 17.3 \\
\hline 籠 （鉒） 数 & 3 & & 6 & \\
\hline
\end{tabular}

\section{A 6. 槍 漁 imiela}

12月になると，漁民は余暇を利用して，カヌー の上から槍で魚を突いて捕獲する。Clarias 属の 魚類は，本来は夜行性であるが，12月に産卵期を むかえ，日中もさかんに活動するようになるので 漁民の目にとまり，多数の魚が槍で捕獲される。 Clarias 属の魚は，体長が $50 \sim 100 \mathrm{~cm}$ 以上になる ので，漁撈キャンプで煄煙作業を行なうことは困 難である。したがって，乙の時期は多数の鮮魚が
河岸の市場に搬入されて価格が下落し，投棄され るととあある，という。

このほか, 夜間にカヌーの先端部に灯油ランプ などの照明を設置し，乙の光に誘導されて集まっ た魚をカヌーから槍で突く漁も行なわれる。漁撈 キャンプよりあスワンプ島周囲の水域で行なわれ るととが多く，筆者はカソマ島に滞在中, Serranochromis angusticeps. Tilapia rendalliなどの 捕獲を確認した。 


\section{A 7. 魚毒法 $u b u b a$}

バングウェウル湖周囲や島の村落付近の小河川, 沼地で行なわれることが多く，スワンプでは観察 できなかった。まず，一定の水域を封鎖して，あ らかじめすりつぶした有毒植物の根, 荃などを水 に注ぎ込む。スワンプ域，とくに漁掞キャンプ付 近では水域を封鎖するてとは困難で，魚毒法はス ワンプ漁法とはいい難い。おもに女性によってお こなわれることも，特徴の1つにあげられる。調 查キャンプにおける聞き込みであ，魚毒植物に関 する知識は女性の方が豊富にもっていた。グンボ やウンガのインフォーマントは, 彼らが用いる魚 毒植物として，表 $5 \mathrm{a}$ に示す 5 種をあげた。乙れら の多くは未同定であるが，ムバラのMoto Moto 博物館では, 表 $5 \mathrm{~b}$ に示す 7 種を魚毒植物として指 摘している。

表 5. 魚毒植物

a. 調査キャンプにおける聞き込みによる

\begin{tabular}{|c|c|}
\hline 方 & 学 \\
\hline$a k a b a$ & ? \\
\hline akapofwe & ? \\
\hline akasusu & ? \\
\hline akacene & ? \\
\hline imibaka & amblygonocarpus andongensis \\
\hline
\end{tabular}

b. Moto Moto 博物館展示による

\begin{tabular}{ll}
\hline \multicolumn{1}{c}{ 方 名 } & \multicolumn{1}{c}{ 学 } \\
\hline kansakata & Clolichos spp. \\
kobamushi & Tephrosia vogeli \\
mufinsa & Syzygium guineense sub sp. \\
munengene & Swartzia madagascariensis \\
nakancete & Bersoma abyssinica \\
cibonimusuba & Euphorbia spp. \\
kanyyemya & $?$ \\
\hline
\end{tabular}

\section{B. 営利漁法}

スワンプで行なわれる営利漁法は, 漁網によっ て大量に漁獲を獲得することを目的とするもので ある。前述のとおり，A5. 鉒漁も営利を目的とし て行なわれることがあるが，営利漁法は，B1. 定 置の刺網漁, B2. 地曳網漁, B3. 追い込み漁に大
別できる。

B1a. 1 晚定置の刺網

浮子 (amakoloko) と沈子 (amabwe) 付きの漁 網 (umusumbu) を, 午後 $4 \sim 5$ 時頃静水中に設 置して，翌朝回収する。前述のとおり，1 枚の網 の全長は, 約 $90 \mathrm{~m}$ である。乙の漁法は, 雨季の初 期（12 1月）と末期（ $4 \sim 5$ 月）に, 営利漁法 としてさかんに用いられる。この期間は降雨が頻 繁でスワンプの水位が上昇し, 漁民の活動が制限 されるために他の営利漁法は行なえない。他の期 間にも多くの漁民が malalikishya 漁を行なうが, 網の設置日は不規則で網数も少なく，その漁獲は 各漁撈ユニットで自家消費されるにすぎない。

ここでは，網のメッシュ・サイズによる漁獲内 容の差異を指摘しておきたい。調査期間中に記録 された malalikishya 漁による漁獲内容を表 6 に示 す。メッシュ・サイズが 1.5 インチ（約 $3.8 \mathrm{~cm}$ ) の漁網之，それ以上のサイズの漁網による漁獲内 容を比較すると，以下の点があげられる。まず， 1. 5 インチの網を使用した時の漁獲は，表に示す ようにTilapia sparmanii (matuku), Marcusenius macrolepidotus (mintesa) に集中する傾向 があるが，1.5 インチより大きい網の漁獲は $m i-$ ntesaの比率が低く, matuku以外のシクリッド 科魚類が増加して漁獲内容が多様になる。Ichikawa（前掲, pp. 34-35）に従い，次の式に示され る種多様度指数（Simpson, 1949）を, 表 6 に示 した魚種別の漁獲重量比率から算出した。

種多様度指数 $=\frac{1}{\sum_{i=1}^{n}(P i)^{2}}$

$P i ：$ i番目の魚種の漁獲重量比率

$n:$ 捕獲魚の種数

それによると，メッシュ・サイズが 1.5 インチ より大きい網による漁獲は, 種多様度指数が 1.5 インチ網の 2 倍以上にのぼっている（表 6 )。ての 漁法を，季節を問わず小規模におてなう漁民の多 くは，1.5インチより大きい網を用いており，雨季に 入った12〜 1月にモルミルス科魚類の捕獲を目的 に malalikishya漁を行なう漁民はすべて, 1.51 
表 6. Malalikishya 漁に上る漁獲内容

(a), (b)は1983年, (c)は1985年に記録

\begin{tabular}{|c|c|c|c|}
\hline \multirow{3}{*}{ 魚 } & \multicolumn{3}{|c|}{ メッシュ・サイズ } \\
\hline & \multicolumn{2}{|c|}{ (a)1.5インチより大 (b)1.5インチ } & \multirow{2}{*}{$\begin{array}{l}\text { (c)1.5インチ } \\
\mathrm{kg}(p i)\end{array}$} \\
\hline & $\mathrm{kg}(p i)$ & $\mathrm{kg}(p i)$ & \\
\hline Mormyrus longirostris Boulenger & $0.9(0.012)$ & & \\
\hline Mormyrops deliciosus (Leach) & $0.4(0.005)$ & $0 \quad(0)$ & \\
\hline Marcusenius monteirii (Gunther) & $0.7(0.009)$ & $0.5(0.001)$ & $0.7(0.004)$ \\
\hline M. macrolepidotus (Peters) & $10.3(0.135)$ & $252.3(0.467)$ & $56.0(0.349)$ \\
\hline Petrocephalus simus Sauvage & $0.1(0.001)$ & $0.3(0.001)$ & $0.1(0.001)$ \\
\hline P. catostoma (Peters) & $0.4(0.005)$ & $14.6(0.027)$ & $22.0(0.137)$ \\
\hline Hydrocyon vittatus Castelnau & $2.0(0.026)$ & $0.1(0)$ & $0.2(0.001)$ \\
\hline \multicolumn{4}{|l|}{ Alestes grandisquamis Boulenger } \\
\hline A. macropthalmus Gunther & & $0.3(0.001)$ & $0.9(0.006)$ \\
\hline A. imberi Peters & $0.2(0.003)$ & $0.1(0)$ & \\
\hline Distichodus maculatus Boulenger & & $0.4(0.001)$ & \\
\hline Barbus banguelensis Boulenger & $0 \quad(0)$ & $0.5(0.001)$ & $0.4(0.002)$ \\
\hline \multicolumn{4}{|l|}{ Labeo altivelis Peters } \\
\hline Schilbe mystus (Linneaus) & $0.5(0.007)$ & $3.1(0.006)$ & $0.3(0.002)$ \\
\hline \multicolumn{4}{|l|}{ Clarias gariepinus Peters } \\
\hline C. ngamensis Castelnau & $7.4(0.097)$ & $26.1(0.048)$ & $6.7(0.042)$ \\
\hline C. obscurus Poll & & $1.9(0.004)$ & \\
\hline C. theodorae Weber & & $10.6(0.020)$ & $0.4(0.002)$ \\
\hline C. buthpogon Sauvage & $0.2(0.003)$ & $3.8(0.007)$ & $3.2(0.020)$ \\
\hline \multicolumn{4}{|l|}{ Heterobranchus longifilis Valanciennes } \\
\hline \multicolumn{4}{|l|}{ Syndontis ornatipinnis Boulenger } \\
\hline S. nigromaculatus Boulenger & $0.2(0.003)$ & $2.7(0.005)$ & $4.3(0.027)$ \\
\hline \multicolumn{4}{|l|}{ Chrysichthys mabusi Boulenger } \\
\hline Auchenoglanis occidentals C.\&V. & $1.3(0.017)$ & $0.8(0.001)$ & $0.5(0.003)$ \\
\hline Sarotherodon macrochir Boulenger & $4.8(0.063)$ & $1.6(0.003)$ & \\
\hline Tilapia rendalli Domeril & $7.3(0.096)$ & $2.0(0.004)$ & $0.1(0.001)$ \\
\hline T. sparmanii Smith & $16.5(0.217)$ & $182.5(0.338)$ & $44.7(0.279)$ \\
\hline Serranochromis angusticeps (Boulenger) & $10.1(0.133)$ & $2.9(0.005)$ & $8.8(0.055)$ \\
\hline S. robustus (Gunther) & & $0.8(0.001)$ & \\
\hline S. thumbergi (Castelnau) & $2.5(0.033)$ & $0.8(0.001)$ & $3.9(0.024)$ \\
\hline Haplochromis mellandi (Boulenger) & $8.2(0.108)$ & $29.7(0.055)$ & $7.1(0.044)$ \\
\hline Tylochromis bangwelensis Regan & $2.1(0.028)$ & $1.3(0.002)$ & $0.1(0.001)$ \\
\hline Ctenopoma multispinis Peters & & $0 \quad(0)$ & $0 \quad(0)$ \\
\hline 総 漁 獲 量 & $76.1(1.000)$ & $539.7(1.000)$ & $160.4(1.000)$ \\
\hline モルミルス科魚類 & $12.8(0.168)$ & $267.7(0.496)$ & $78.8(0.491)$ \\
\hline 種 多 様 度 指 数 & 8.33 & 2.96 & 4.52 \\
\hline 漁 網 数 & 43 & 214 & 56 \\
\hline 漁 網 当りの漁獲量 & 1.77 & 2.52 & 2.86 \\
\hline
\end{tabular}

ンチ網を用いるのである。1.5 インチ網による漁 獲は, 次項に述べる ukusebeshya漁より漁獲種の 選別性は低いが，その代替漁法として雨季に用い れば，効果的に漁獲をあげることができるのであ る。
B1b. 夜間数時間定置の刺網 ukusebeshya

この漁で使用する漁網は前項の 1 晚定置網漁と 同じタイプだが，メッシュ・サイズ 1.5 ンチ(約 $3.8 \mathrm{~cm})$ の網が用いられるのが普通であり, 網の 静置時間は $3 \sim 4$ 時間以内で，その間は漁民が網 
の設置点の近くに待機する点に，大きな特徵があ る。漁時間帯は, 宵の口（午後 $4 \sim 8$ 時）之明け 方（午前 $1 \sim 5$ 時）があり，それぞれ別個に行なわ れ, ukusebeshya icungulo (宵の口漁), ukusebeshya kumaca（明け方漁）と呼ばれる。乙の漁 に出漁する漁民は，全長約 $90 \mathrm{~m}$ の網をカヌーに数 枚載せ，宵の口漁には午後 4 時頃，明け方漁には 午前 1 時頃にキャンプを出発する。彼は漁場 (ifyelo）に網を設置してその付近に待機し， $3 \sim 4$ 時間後に網を回収してキャンプに戻る。網の設置 後も漁民がその場に待機するのは，静置時間中に カワウソ (mukobe) やClarias属の肉食魚 $(m u-$ ta）などが漁獲を食い荒し，漁網が破られてしま うのを防ぐためである。実際，1晚定置網漁を行 なう漁民は，しばしば漁獲や漁網に被害を受ける。 漁獲がワニに襲われることあある，という。

網の設置点 (ifyelo) としては, 日中その下に モルミルス科魚類がひそんでいる，といわれる浮 き島（sela）の近くが選ばれる。 sela とは，水面 上に出ている草本類を意味し, その水面下は imikoma之呼ばれる。漁民によれば，モルミルス科 魚類はicungulo（宵の口）に活動を開始し，それ はkumaca（明け方)に終了する，という。漁民は， 夜行性のモルミルス科魚類の日中の休息場所付近 に，魚の活動の開始と終了時間帯に合わせて漁網 を設置するのである。海洋，内水面を問わず，特 定魚類の集中的な捕獲を目的に $3 \sim 4$ 時間だけ刺 網を静置する，乙れと同種の漁法の存在は，現在 まで世界各地のどてからも報告されていない。以 下に，乙の漁法による漁獲を分析，検討する。

1983年の調查期間中に記録された霄の口漁の 漁獲（表 7 ）に拈いては, Marcusenius macrolepidotus (mintesa). Tilapia sparmanii ( $m a-$ $t u k u)$ ，の両種が圧倒的に多く，それぞれ総重量 中の $47.4 \%, 34.5 \%$ をめる。また，モルミル ス科, シクリッド科魚類の漁獲量を合計すると, 両科で全重量の $97.6 \%$ をしめる。明け方漁の漁 獲でも, mintesa,matukuの 2 種が他種を圧倒し ているが，漁獲重量は mintesaが matukuの 4 倍 以上に達する。モルミルス科，シクリッド科魚類 の漁獲重量は，全体の $95.9 \%$ \% る。1 1985年
に，別の水域にある調査キャンプで記録したての 漁でも，宵の口，明け方漁の漁獲を合わせて $m i$ ntesa が総重量の $95.4 \%$ \%め, モルミルス科 魚類の重量む全体の $95.4 \%$ に達した（表 7 ）。 Simpson の多様度指数は 1.10 であり, 漁獲はモル ミルス科魚類, とくにMarcusenius macrolepidotus (mintesa) に集中していた。漁民自らも mintesaの捕獲を望み, それを期待してukusebesh$y a$ 漁を行なうのである。乙の漁では, シクリッ ド科の小型魚である Tilapia sparmanii (matuku）の漁獲む多いが，乙の魚は小骨が多いので漁 民に好まれず，その捕獲はあまり歓迎されない。 スワンプには蚊が多数棲息するが，夜間網の設置 点にカヌーを止め，その上で待機する漁民は，蚊 の襲来から逃れることはできない。彼らは，おび ただしい数の蚊に悩まされ，大きな苦痛を味わう ことになる。それにあかかわらず，モルミルス科 魚類, とくに mintes $a$ を捕獲するために, 多くの 漁民は毎晚のように ukusebeshya 漁に出漁する。

ザンビアでは，各漁場の漁民組織がその地域の 漁獲売り渡し価格を決定し，それは人びとに遵守 されている。調査地域の漁民組織は，スワンプへ の中継村落であるチンサンカ（Cinsanka）に事務 所を持ち,

Fisherman's Association of Zambia,

Cooperative Union at Cinsanka と呼ばれている。漁撈キャンプで，漁民が商人に 乾燥魚を売り渡す際の価格は, 1985 年の調査時 には魚種にかかわらず $1 \mathrm{~kg}$ あたり 3.5 ザンビア・ クワチャであった。（1 米ドル＝約 6 ザンビア・ クワチャ)

筆者は, サンフィヤの市場のほかに，サンフィ ヤから約 $100 \mathrm{~km}$ 離れたルアプラ州の州都マンサ (Mansa), コッパーベルト州の大都市キトゥエ （Kitwe）の市場においても，魚類（乾燥魚）の 市場価格を記録した（表 8 )。乙れらはいずれも， バングウェウル・スワンプで獲れた魚が流通し, 消費される都市や町である。漁民はスワンプにお いて，どの魚も同じ価格で売り渡すが，市場では 魚種によって価格に差異が生じている。なかでも， mintesaの価格上昇は著しく，キトゥエではスワ 
表 7. Ukusebeshya 漁による漁獲内容

\begin{tabular}{|c|c|c|c|}
\hline 魚 & $\begin{array}{l}\text { 宵の口漁 } \\
(1983 \text { 年) } \\
\text { kg }(p i)\end{array}$ & $\begin{array}{c}\text { 明け方漁 } \\
(1983 \text { 年) } \\
\text { kg }(p i) \\
\end{array}$ & $\begin{array}{c}\text { 宵の口, 明け方漁 } \\
\text { (1985年) } \\
\text { kg }(p i)\end{array}$ \\
\hline Mormyrus longirostris Boulenger & $0.6(0.001)$ & $0.2(0)$ & \\
\hline Mormyrops deliciosus (Leach) & $3.0(0.003)$ & $3.8(0.004)$ & \\
\hline Marcusenius monteirii (Gunther) & $40.4(0.035)$ & $17.9(0.021)$ & \\
\hline M. macrolepidotus (Peters) & $550.4(0.474)$ & $580.8(0.682)$ & $25.1(0.954)$ \\
\hline Petrocephalus simus Sauvage & $5.7(0.005)$ & $5.6(0.007)$ & $0 \quad(0)$ \\
\hline P. catostoma (Peters) & $75.0(0.065)$ & $64.8(0.076)$ & \\
\hline Hydrocyon vittatus Castelnau & $2.5(0.002)$ & $0.6(0.001)$ & \\
\hline Alestes grandisquamis Boulenger & $0.1(0)$ & $0.1(0)$ & \\
\hline A. macropthalmus Gunther & $1.3(0.001)$ & $1.2(0.001)$ & \\
\hline A. imberi Peters & $3.7(0.003)$ & $2.1(0.002)$ & \\
\hline Distichodus maculatus Boulenger & $1.1(0.001)$ & $1.0(0.001)$ & \\
\hline Barbus banguelensis Boulenger & $0.5(0)$ & $1.1(0.001)$ & \\
\hline \multicolumn{4}{|l|}{ Labeo altivelis Peters } \\
\hline Schilbe mystus (Linneaus) & $11.6(0.010)$ & $18.6(0.022)$ & \\
\hline \multicolumn{4}{|l|}{ Clarias gariepinus Peters } \\
\hline C. ngamensis Castelnau & $1.1(0.001)$ & $1.0(0.001)$ & \\
\hline C. obscurus Poll & $0.6(0.001)$ & $0.1(0)$ & \\
\hline \multicolumn{4}{|l|}{ C. theodorae Weber } \\
\hline C. buthpogon Sauvage & $0.4(0)$ & $0.2(0)$ & $0.1(0.004)$ \\
\hline \multicolumn{4}{|l|}{ Heterobranchus longifilis Valanciennes } \\
\hline Synodontis ornatipinnis Boulenger & $0 \quad(0)$ & & \\
\hline S. nigromaculatus Boulenger & $2.7(0.002)$ & $7.8(0.009)$ & $0.1(0.004)$ \\
\hline Chrysichthys mabusi Boulenger & $0.2(0)$ & $0.4(0)$ & \\
\hline Auchenoglanis occidentalis C.\&V. & $1.2(0.001)$ & $0.5(0.001)$ & \\
\hline Sarotherodon macrochir Boulenger & $7.0(0.006)$ & $1.6(0.002)$ & \\
\hline Tilapia rendalli Domeril & $4.0(0.003)$ & $0.9(0.001)$ & \\
\hline T. sparmanii Smith & $400.9(0.345)$ & $127.4(0.150)$ & $0.8(0.030)$ \\
\hline Serranochromis angusticeps (Boulenger & r) $7.1(0.006)$ & $2.7(0.003)$ & $0.1(0.004)$ \\
\hline$S$. robustus (Gunther) & $1.0(0.001)$ & $0.4(0)$ & \\
\hline S. thumbergi (Castelnau) & $3.0(0.003)$ & $0.4(0)$ & $0.1(0.004)$ \\
\hline Haplochromis mellandi (Boulenger) & $26.9(0.023)$ & $7.6(0.009)$ & \\
\hline Tylochromis bangwelensis Regan & $9.0(0.008)$ & $2.1(0.002)$ & \\
\hline Ctenopoma multispinis Peters & $0.1(0)$ & $0.1(0)$ & $0 \quad(0)$ \\
\hline 総漁獲 量 & $1,161.1(1.000)$ & $851.0(1.000)$ & $26.3(1.000)$ \\
\hline$モ ル ミ ル ス$ 科魚類 & $675.1(0.581)$ & $673.1(0.791)$ & $25.1(0.954)$ \\
\hline シクリッド科魚類 & $458.9(0.395)$ & $143.1(0.168)$ & \\
\hline 種 多 様 度 指 数 & 2.86 & 2.02 & 1.10 \\
\hline 漁 網 数 & 577 & 375 & 22 \\
\hline 漁 網 当りの漁獲 量 & 2.01 & 2.26 & 1.20 \\
\hline
\end{tabular}

ンプの12倍以上の価格で販売されている。このた め, 漁獲購入のためにスワンプを訪れる商人の間 であ, mintesa をはじめとするモルミルス科魚類 の需要は高く, 漁民自身の嗜好之相まって, $u k u$ sebeshya 漁がさかんに行なわれている，亡考え
るととができる。この漁に従事する漁民の多くは， 1 日に 2 回（霄の口漁と明け方漁）出漁するので ある。

また，乙の漁の主漁獲である mintesaは，体長 $20 \mathrm{~cm}$ 以下で体重む $100 \mathrm{~g}$ に満たない個体が大半を 
表 8. ザンビア各地における乾燥魚の市場価格（1985年11月）

\begin{tabular}{llcccc}
\hline \multicolumn{1}{c}{ 魚 種 } & 方名 & スワソプ & サンフイ & マンサ & キトゥエ \\
\hline Tilapia sparmanii & matuku & 3.5 & 5.56 & 7.5 & 13.33 \\
Marcusenius macrolepidotus & mintesa & 3.5 & 10.0 & 15.0 & 42.86 \\
Serranochromis angusticeps & $\begin{array}{l}\text { polwe } \\
\text { mpende }\end{array}$ & 3.5 & 4.88 & 12.0 & 13.64 \\
Tilapia rendalli & 9.5 & 13.64 & - \\
Sarotherondon macrochir & $\begin{array}{l}\text { nkamba } \\
\text { Clarias gariepinus }\end{array}$ & & & & \\
muta & 3.5 & - & 12.0 & 8.33 \\
C.ngamensis & muta & & & & $(\mathrm{K} . / \mathrm{kg})$ \\
\hline
\end{tabular}

一:未確認， K.:ザンビア・クワチャ.

しめるので, 漁網 (約 $90 \mathrm{~m}$ ) あたりの漁獲量は 2 〜 $3 \mathrm{~kg}$ にどまる（表 6,7）。この漁法によって， 漁獲を営利目的に蓄積するためには，数多くの漁 網が必要になる。調査キャンプでこの漁法を採用 する漁掞ユニットは，どれも 1 日に10枚以上の漁 網を定置していた。

mintesa 以外の魚を捕獲するために, ukusebeshya 漁が行なわれるととあある。前述のとおり, ての漁法では一般にメッシュ・サイズ 1.5 インチ (約 $3.8 \mathrm{~cm}$ ）の漁網が用いられ, mintesa が集中的 に捕獲される。ところが 1985 年の調查期間中, 筆者はメッシュ・サイズ 0.5 ンチ (約 $1.27 \mathrm{~cm}) の$ 漁網を用いた ukusebeshya 漁を観察し，その漁獲 内容を記録することができた（表 9 )。てれは ukusebeshya cise と呼ばれ, 漁民の捕獲目標が, Petrocephalus simus (cise) という体長 $5 \mathrm{~cm}$ にも満 たない魚種である点に特徴がある。漁獲は cise と mintesaに集中し, 両種で総尾数の $77.3 \%$, 総重 量の $68.1 \%$ しめるのである。 ciseは mintesa よ りあ小型で, メッシュ・サイズ1.5インチの網で はあまり捕獲されない（表 6,7）ために, 漁民はメ ッシュ・サイズがさらに小さい網を用いるのであ る。また，乙の漁では漁網 1 枚（約 $90 \mathrm{~m} ）$ あたり の漁獲量が $4.99 \mathrm{~kg}$ (表 9 ) で, 前述の malalikishya 漁やメッシュ・サイズ1.5インチの ukusebeshya 漁よりも捕獲効率は高い。しかし，この 漁法による漁獲はほとんど売却されない。メッシ ュ・サイズ 0.5 インチ（約 $1.27 \mathrm{~cm} ）$ の漁網は少数 の漁民しか持たず，全長が50ヤード（約 $45 \mathrm{~m} ） を$ 越える網屯少ない。ほとんどの漁民は宵の口漁し か行なわず，乙の漁は「おかずとり」の色彩が強
い，といえよう。市場では ciseに対する需要が低 く，商人はこの魚の購入を好まないが，漁民の間 では，食料として㕰好されている。したがって， 彼らは小さいメッシュ・サイズの網を用いて，少 ない捕獲努力で効率よくこの魚を捕えるのである。

B1c. 数日間定置の刺網 mutobi

定置の刺網という点では前記の 2 法 (B1a.b) と 同じだが，大型魚の捕獲を目的とし，網糸が太く， メッシュ・サイズが 4 インチ（約 $10.2 \mathrm{~cm}$ ）以上の 網を，同地点に数日間定置し続ける点が異なる。 網を設置した漁民は毎日それを点検し，網を設置 したまま漁獲だけを取り出す。このような漁獲回 収法は ukulola といわれ, malalikishya,ukusebeshya 漁においても，網数が少なければての方式 で漁獲が回収されるこ之がある。網の点検と漁獲 の回収は数日間くり返され, 日々の漁獲が減少す ると設置点は移される。

この漁法では, 網のメッシュ・サイズが大きい ので，漁獲魚のサイズあ大きい。Tilapia rendalli (mpende), Serranochromis robustus ( $n s u$ ku). Auchenoglanis occidentalis (mbowa) な どの，体長 $30 \mathrm{~cm}$ 以上の魚が，乙の漁法によって捕 獲される。漁獲魚は大型だが，漁網あたりの漁獲 数は少なく(10尾前後)，1 度に設置される漁網 1〜2枚にとどまるので, 通漁期的にみた漁獲量 は前記の 2 法には及ばない。この漁を行なう漁民 は，漁獲を自家消費することああるが，後節に述 べる mukombo漁による漁獲に付加して利用する ことが多い。

B1d. 日中数時間定置の刺網 mapila 筆者の調査キャンプでは行なわれていなかった 
表 9. Ukusebeshya cise 漁による漁獲内容

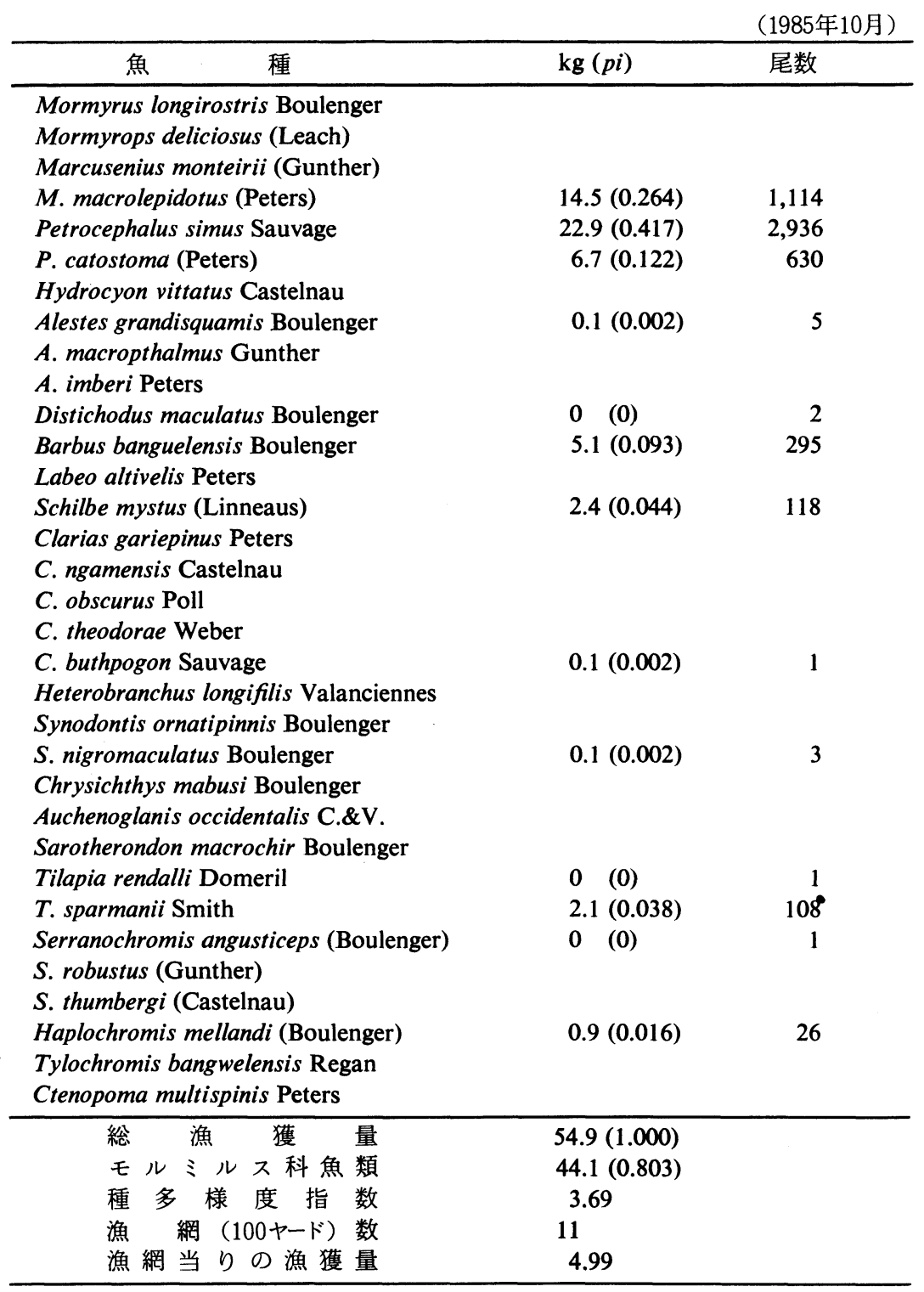

が, Ichikawa(前掲, p.34)によれば，日中に定置す る刺網漁あある，という。この漁法は，スワンプ 域では積極的に行なわれず, 漁獲む多く得られな いので，営利漁法として分類するのは適切でない かもしれない。しかし，筆者は1985年 12 月にム ウェル・ワンティパ湖において, 漁網を早朝に設 置して夕方に回収する mapila 漁が行なわれ，Ti- lapia sparmanii やSerranochromis angustice$p s$ が捕獲されるのを観察した。

\section{B2. 地曳網 mukwao}

営利漁法として曳網を採用する漁撈ユニットあ あり, これは地曳網 (mukwao) と, カヌー上か らの电網（kapopela）に分けられる。kapopela 
漁は, 水面が開けて水深が深い湖面でなければ行 なえないが, mukwao漁は, 開水面の狭いスワン プでも行なうことができる。スワンプ域における 地曳網では流水が利用され，乙の点は静水域を漁 場とする定置網漁（B1a～d）とは異なる。

mukwao 漁では, 漁撈ユニット内の $3 \sim 4$ 名 が 1 組になり，1〜2 そうのカヌーに乗りてんで 漁場に向かう。そして, 流れのある水路内を漁場 （icelo）に選び, 曳網専用に作られた, 中央部の 深い網を展開する。まず, 網の 1 端に付けられた matepa と呼ばれる全長約 $1 \mathrm{~m}$ の手木を岸に固定 し，たたまれた網を，曳き縄（amalushi）の付い ている他の端から徐々に水中に伸ばしていく。網 が弧状に伸びきると, 固定した手木の近くで 1 人 が曳き縄を曳き始め, 網を岸に寄せる。別の 1 人 は手木が流されぬように押さえ，他の 1 人は網の 中央 $(n d u m b a)$ 付近でカヌ一上から障害物を取 り除く。湖岸で網を曳く場合は, 両端の手木に电 き縄の付いた漁網が用いられ, 漁民は互いに5〜 $10 \mathrm{~m}$ 離れた 2 地点から曳き縄を曳く。しかし，ス ワンプでは 2 力所から網を曳くととのできる地域 が少ない。網を岸に曳き寄せると，漁民はそれを カヌー上に揚げて漁獲を取り出す。

この漁にも, ukusebeshya 漁のような夜間漁が 普及しており, icungulo（宵の口）漁とkumaca （明け方）漁に区別される。日中に地曳網漁を行 なう漁掞ユニットも多く, 日中の漁は mukwao $a k a s u b a$ 之呼ばれる。宵の口漁では午後 $4 \sim 5$ 時 にキャンプを出て活動し, 午後 $8 \sim 9$ 時頃に戻る。 この漁を 1 日に 2 回（霄の口漁之明け方漁）行な う漁掞ュニットの漁民は, 宵の口漁の漁獲を漁場 で網からはずしてキャンプに戻り，2〜3時間休 息した後, 午前 $1 \sim 2$ 時頃明け方漁のために再び キャンプをあとにする。彼らは，浮き島 ( sela) に面した水路に網を設置し，宵の口漁では，魚が 浮き島の下から動き始める頃に曳き縄を曳き, 明 け方漁では浮き島の下に戻ってくる魚を捕えるて とになるので, 原理的には前記の ukusebeshya 漁 と同じである。

1983年の調査で記録された mukwao 漁の漁獲 内容によれば, 夜間漁の漁獲はモルミルス科魚類,
中でも mintesa に集中し, 種多様度指数も低い （表10）。乙れとは対照的に, 日中漁の漁獲はシク リッド科魚類に集中する。漁獲される魚類が, Sarotherodon macrochir (nkamba), Tilapia rendalli (mpende). Tilapia sparmanii ( $m a-$ tuku）の 3 種に分散しているが, 漁獲の種多様度 指数は夜間漁と大差ない（2.98）。ukusebeshya 漁においては, Tilapia sparmanii (matuku) が mintesaをしのいで多量に捕獲されることあある が, 夜間の mukwao 漁では, 相対的にわずかし か捕獲されない（表10）。漁民によれば，matu$k u$ は流水中であまり活動しないが, mukwao 漁 は流水域で行なわれるので, matuku は捕獲され ない,という。

\section{B3. 追い込み漁 mukombo}

mukombo 漁は, ザンビア特有の追い込み漁で ありムウェル湖方面では, kutumpula とあ呼ばれ る（Mortimer, 前掲, p.34)。調查地域では, $m$ ukombo 漁に出漁するととを ukusakila という。

この漁に用いられる漁網は kacaala と呼ばれ, 沈子が付けられておらず，全長 $20 \sim 40 \mathrm{~m}$, メッシ ュ・サイズは $2 \sim 3$ インチ $(5 \sim 7.6 \mathrm{~cm})$ と大き く, 大型魚の捕獲が目的とされる。

網の設置点（icelo）としては, 水深が浅く, パ ピルスなどの密生していない水域が選ばれる。な かであ，ハリイの 1 種 Eleocharis dulcis (amashinge）がまばらに生えた水域や, 水底に mpende などシクリッド科の魚が作った巣 (imilindi) が見られる水域が好まれる。

漁民は，まず水面を覆う草本類を取り除いてか らkacaalaを張り始める。前述のように, kacaala には沈子が付けられていないので, 漁民は櫂など を用いて網の下端を水底の泥に押し込んで網を広 げる。 kacaala を張り終えると，漁民は魚を追い 込む水域を避けながら, kacaala から50〜 60 m 離 れた地点まで弧を描くようにカヌーで移動して待 機する。移動を終えた漁民は, akatole と呼ばれ る全長 $1.5 \sim 2 \mathrm{~m}$ の, 乙の漁専用の吒き棒で水面 を打ちながら, kacaala に向かってカヌーを進ま せる。 kacaala を設置し, 水面を打って魚を追い 
表10. Mkwao 漁に上る漁獲内容

1983年10１2月

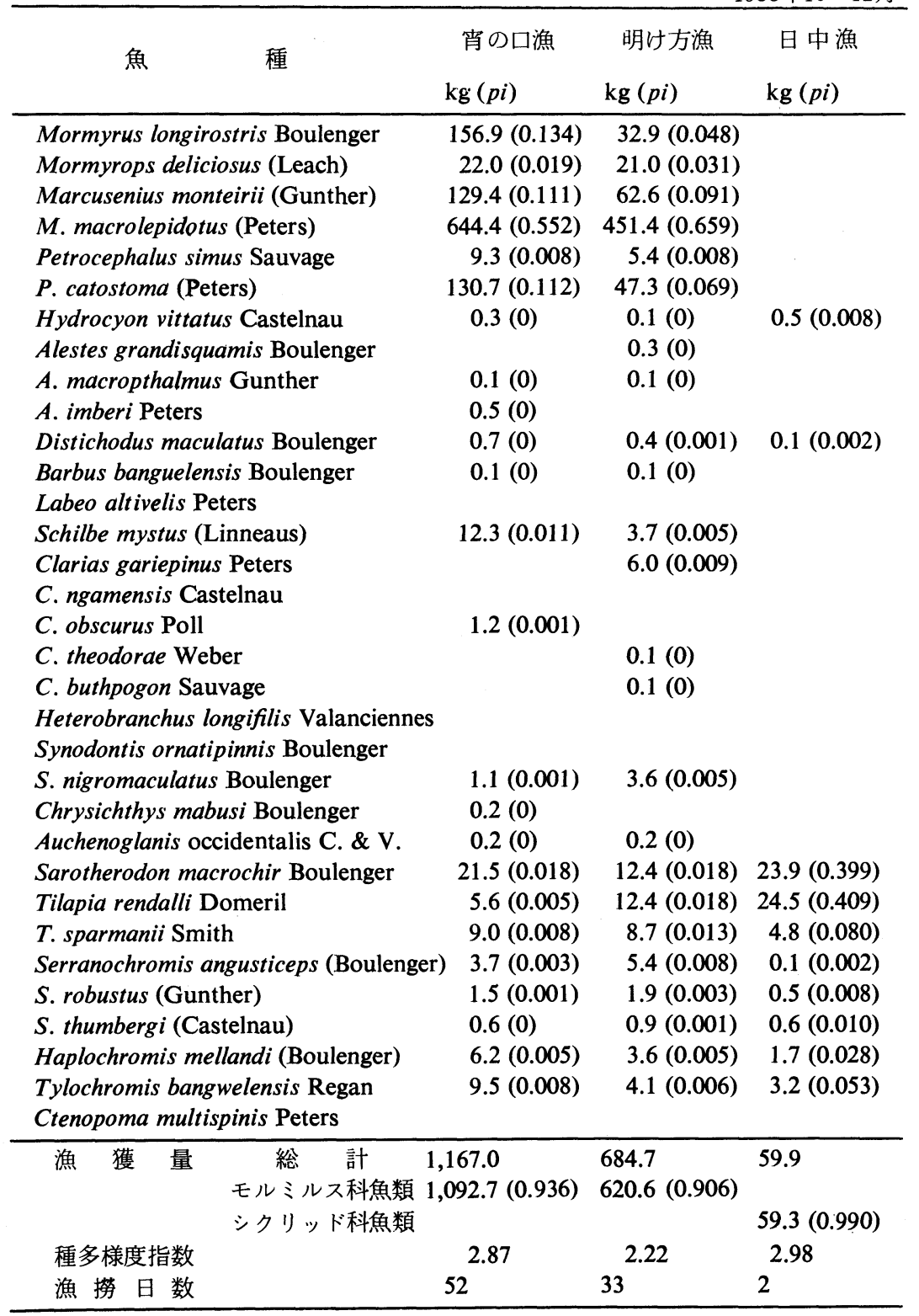

込み, 漁獲と kacaala を回収する過程をukusaki$l a$ といい, 通常は約 1 時間を要する。漁民は, $u$ kusakila ごとに移動して iceloを変えながら，1 日に数回の ukusakila を行なう。通常は，数人の 漁民が 1 団（abamukombo）となってての漁を行
なうが，単独で出漁する漁民も存在する。Ichikawa（前掲, pp.41-42）は, mukombo 漁におり る集団漁の意義について, 漁獲効率という点から 分析したが，単独漁之集団漁の間には，1 人あた りの漁獲量に明確な差異は見られなかった。筆者 
（前掲，pp.74-75）の結論屯同様で, abamukomboは単独漁民の集合体の様相を呈するが，土 地利用の面からは，一定水域が順次利用されてい

くこと,などを指摘した

表11に示すように，乙の漁の漁獲はシクリッド 科魚類に集中する 1983 年の調査で得た漁獲記 録によれば，シクリッド科の 3 魚種 Sarotherodon macrochir (nkamba), Tilapia rendalli (mpende), Tylochromis bangwelensis (nsangula)が 漁獲重量の $87.9 \%$ \%をめなかであ mpende は $58 \%$ に達する。1985 年に得た漁獲記録において 屯, 漁獲はすべてシクリッド科魚類, とくに $m p$ ende に集中し，その重量比は $72.4 \%$ であった。 Ichikawa（前掲，p. 36 ) の記録では，シクリッ

表11. Mukombo 漁による漁獲内容

\begin{tabular}{|c|c|c|c|c|}
\hline 魚 & $\begin{array}{l}1983 \text { 年 } \\
\operatorname{kg}(p i)\end{array}$ & 尾数 & $\begin{array}{l}1985 \text { 年 } \\
\mathrm{kg}(p i)\end{array}$ & 尾数 \\
\hline \multicolumn{5}{|l|}{ Mormyrus longirostris Boulenger } \\
\hline \multicolumn{5}{|l|}{ Mormyrops deliciosus (Leach) } \\
\hline Marcusenius monteirii (Gunther) & $0 \quad(0)$ & 3 & 3 & \\
\hline M. macrolepidotus (Peters) & $0.4(0)$ & 4 & 4 & \\
\hline \multicolumn{5}{|l|}{ Petrocephalus simus Sauvage } \\
\hline Hydrocyon vittatus Castelnau & $3.2(0.001)$ & 17 & & \\
\hline Alestes grandisquamis Boulenger & $0.1(0)$ & 2 & 2 & \\
\hline A. macropthalmus Gunther & $0 \quad(0)$ & 1 & 1 & \\
\hline A. imberi Peters & $0 \quad(0)$ & 3 & 3 & \\
\hline \multicolumn{5}{|l|}{ Distichodus maculatus Boulenger } \\
\hline \multicolumn{5}{|l|}{ Barbus banguelensis Boulenger } \\
\hline \multicolumn{5}{|l|}{ Labeo altivelis Peters } \\
\hline Schilbe mystus (Linneaus) & $0.5(0)$ & 6 & 6 & \\
\hline Clarias gariepinus Peters & $39.7(0.017)$ & 89 & & \\
\hline \multicolumn{5}{|l|}{ C. ngamensis Castelnau } \\
\hline \multicolumn{5}{|l|}{ C. obscurus Poll } \\
\hline \multicolumn{5}{|l|}{ C. theodorae Weber } \\
\hline C. buthpogon Sauvage & $0.8(0)$ & 1 & & \\
\hline \multicolumn{5}{|l|}{ Heterobranchus longifilis Valanciennes } \\
\hline \multicolumn{5}{|l|}{ Synodontis ornatipinnis Boulenger } \\
\hline \multicolumn{4}{|l|}{ Chrysichthys mabusi Boulenger } & \\
\hline Auchenoglanis occidentalis C.\&V. & $3.7(0.002)$ & 8 & & \\
\hline Sarotherodon macrochir Boulenger & $424.5(0.182)$ & 3,508 & $7.9(0.114)$ & 41 \\
\hline Tilapia rendalli Domeril & $1,352.1(0.581)$ & 9,989 & $50.25(0.724)$ & 342 \\
\hline T. sparmanii Smith & $13.1(0.006)$ & 294 & & \\
\hline Serranochromis angusticeps (Boulenger) & r) $118.2(0.051)$ & 695 & $3.1(0.045)$ & 16 \\
\hline S. robustus (Gunther) & $17.0(0.007)$ & 55 & $0.2(0.003)$ & 1 \\
\hline S. thumbergi (Castelnau) & $59.2(0.025)$ & 307 & $6.5(0.094)$ & 36 \\
\hline Haplochromis mellandi (Boulenger) & $25.5(0.011)$ & 246 & $0.4(0.006)$ & 3 \\
\hline Tylochromis bangwelensis Regan & $270.5(0.116)$ & 3,077 & $1.1(0.016)$ & 6 \\
\hline \multicolumn{5}{|l|}{ Ctenopoma multispinis Peters } \\
\hline 総 漁 獲 量 & $2,328.5(1.000)$ & & $69.45(1.000)$ & \\
\hline 種多様度指数 & 2.57 & & 1.82 & \\
\hline 漁 势 日 数 & 197 & & 10 & \\
\hline
\end{tabular}


ド科の他種 Serranochromis angusticeps (polwe), Serranochromis thumbergi (ntasa) の漁 獲がやや多い。乙れは，水域による魚種構成の差 異が漁獲に反映されたもの，ととらえることがで きようが，いずれあ mukombo 漁にたずさわる漁 民の期待に沿った漁獲内容である。 mukombo 漁 による漁獲は，体長 $20 \sim 40 \mathrm{~cm}$, mpende をはじ めとするシクリッド科魚類なのである。

\section{B4. 流し網 ukukunguluka}

調査キャンプでは観察されなかったが，ルアプ ラ川などの河川や幅の広い水路で行なわれる。水 流に垂直に網を張り，流れにまかせて短時間下流 に流して魚を捕獲する。川や水路を遡上する Schilbe mystus (lupata) やAlestes macrocephalus (manse) の大量捕獲を目的として行なわれる。

\section{総括}

本章では，スワンプで行なわれる種々の漁法と 漁獲の特徵を述べてきた。ここでは，スワンプで 活動する漁民に共通する以下の特徵が指摘できる。 漁民が漁獲を自家消費するか売却を目的とするか を問わず，彼らは漁獲を特定魚類に集中させるこ とを意図して漁法を選択し，漁を行なうのである。 たとえば, ulwanga漁は規模の小さい漁であるが, はっきりとBarbus banguelensis (mumbulwe) の捕獲が目指され, 漁獲の大半は mumbulweでし められていた（表 4)。特定魚を対象にした漁法 としては, Petrocephalus simus (cise) を対象に メッシュ・サイズの小さい漁網を用いる ukusebeshya cise（表 9), 漁獲の大半が mintesa でしめ られる ubwamba 漁（表 4) や, Ichikawa(前掲, p. 33 ) が報告したSchilbe mystus (lupata) の 追い込み漁，（ukusakila lupata）なよ゙ああげる ことができる。営利を目的にした漁撈をおてなう 各漁撈ユニットは，目指す魚類を集中的に捕獲す ることのできる漁法とメッシュ・サイズを選択し て活動している。夜間の数時間だけ,メッシュ・ サイズ 1.5 インチの網を浮き島付近に設置する ukusebeshya漁により，漁民はMarcusenius macrolepidotus (mintesa) を中心に, モルミルス
科魚類を大量に捕獲して売却することができ，一 方比較的開けた浅水域で mukombo 漁をおこなう 漁民はメッシュ・サイズ 2 インチ以上の網を用い, あっぱら Tilapia rendalli (mpende) をはじめと したシクリッド科の大型魚類を収集して売却する のである。また，同じ漁法を用いても漁撈時間帯 によって漁獲内容が一変するととを, 強調してお かねばならない。すでに指摘したように，mukw$a o$ 漁の漁獲は，日中漁においてはシクリッド科 魚類, 夜間漁に拈いてはモルミルス科魚類が大半 をしめるのである。Ichikawa（前掲，p. 35 ）は， mukwao 漁の漁獲の種多様度指数 (9.84) が高 いととから，総体的には漁獲選別的な漁法といえ ない，と主張する。しかし，漁民が特定魚類の捕 獲を意図して，漁時間帯を使い分けている点は見 逃せない。筆者の調査キャンプで mukwao漁を行 なっていた漁撈ユニットの漁民は日中漁を行なわ ず， mintesa を大量に捕獲するために，夜間漁だ け行なったのである（Imai，前掲，p. 77 ）。

最後に，漁獲内容が特定魚種に偏る，という傾 向があたらされる要因について考察してみたい。 前述のとおり，漁民は漁掞キャンプにおいて，魚 種にかかわらず重量あたり同一の価格で漁獲を売 却するが，市場では魚種による価格差が著しい。 利益を最大化するという観点からは，特定魚を集 中的に捕獲する利点は見出せない。市場の需要に 見合うような漁獲を得るために漁民が活動する, という本章で述べてきた現象は，乙の地域の漁民 が強力に組織化されておらず，個別的に商人と取 引しているてとによって引き起てされる，と思わ れる。漁民の組織化の度合は，ザンビア国内の漁 場によってそれぞれ異なる。筆者が 1985 年に行 なった広域調查の中で，ムウェル湖畔のチェレン ゲ (Nchelenge) では, 漁業協同組合が大部分の 漁獲をまとめ，コッパーベルト州に運搬して売却 する，とのととだった。バングウェウル域におい ては, 前稿（前掲, pp. 84）にも述べたとおり, 商人はシクリッド科の大型魚やモルミルス科魚類 の購入を望み，他種の買い付けを拒否することあ あるが，乙れらの魚類がスワンプで手に入らない 時であ, 他の魚類を同じ価格で購入しなりればな 
らない。したがって，組織化の程度が弱いバング ウェウル・スワンプの漁民は，魚価が魚種によら ず一定であるととによって，流通経斉の圧力から 一定程度保護されている，ととらえるとともでき よう。個々の漁撈ユニットは市場消費者の要請に 則して漁法を選択し，漁獲を円滑に売却するとと を目指している，と考えられる。

また，漁民自身が利用するために魚を捕る場合 にむ，特定の魚が対象とされ，それが集中的に捕 獲されるのである。前述の ulwanga 漁や ukusebeshya cise漁がこれにあたる。このように，漁民 は伝統的に対象となる魚類の習性を知って漁具を 操作し，その場所での自然，生物環境に合わせて 漁獲してきた，といえるのである。

\section{VI 漁民の活動類型}

前章までは，スワンプ内外に本村を持つ漁民た ちが形成する漁撈組織について記し，各漁撈ユ二 ットが行なう漁法をあげて，その漁獲内容の特徵 を指摘した。そして, 各漁撈ユニットは特定魚類 に的をしぼり，それを集中的に捕獲するてとので きる漁法を選択して漁を行ない，漁獲を効率的に 蓄積，利用していることが示された。本章におい ては，スワンプ全域で約 7,000人 (Tait, 前掲, p.

70）とされるが，現在ではそれより多いと思われ る，スワンプ漁民の活動様式を類型化して，居住 地域が異なる複数の民族集団によるスワンプ利用 の実態を把え，それが産み出される要因を考察す る。

前述（ＩI）のように，バングウェウル・スワ ンプの漁民はすべてベンバ語族であるが，漁掞工 ニット（nsanga）は組織化されておらず，それ ぞれが独自に活動している。しかしてれまでの調 查によれば，スワンプ漁民（or漁撈ユニット）の 活動パターンは次の 2 種に分類することができる。 (表 2)

( i ) mukombo (追い込み漁) 型

(ii ) malalikishya (定置の刺網) 型

（i ）型漁民は，4〜11月初旬を漁期とし，4〜 5 月はmalalikishya 漁を行なうが，その後は集約
的に mukombo 漁を行ない, 主として体長 $20 \sim 40 \mathrm{~cm}$ のシクリッド科魚類を捕獲する。大部分の ( i ) 型漁 民の本村はバングウェウル湖北方, スワンプからの距 離が $100 \mathrm{~km}$ 以上に達する地域にあり, 彼らは湖の北岸 からカヌーを漕いでスワンプに入らねばならない。彼 らはグンボ, ムクルと呼ばれる民族集団に属する人び とである(図 3)。(ii) 型漁民は一般に 4〜7月, 10〜1 月にスワンプで漁掞を行なう。彼らは, 定置の刺網漁で ある malalikishya 漁やukusebeshya漁を行ない, 夜行性のモルミルス科魚類を捕獲する。彼らの本 村はスワンプ内に点在する広さ数〜 $10 \mathrm{~km}^{2} の$ 島々

（カソマ, サルシ，チェタなど，図 2 参照）にあ るが，村の周辺ではほとんど漁を行なわず，島か ら数〜 $20 \mathrm{~km}$ 離れた地点に漁撈キャンプ（pamita$n d a)$ を設けて活動する。ウンガと呼ばれる人び とである（図 3 )。湖畔まだはスワンプ周囲の土 地に本村を持つ人びとは，採用する漁法が漁撈二 ニットによって一定しない。 mukombo 漁によっ てシクリッド科魚類を捕獲する（i 型のユニッ トがあり, 定置の刺網漁によってモルミルス科魚 類を収集する（ii）型のユニットあある。地曳網 （mukwao）漁や鉒（ubwamba）漁を採用して, まとまった漁獲を得るユニットあある。彼らの本 村は，スワンプ漁場からの距離が40〜 $50 \mathrm{~km}$ で, (i )

（ii ）型漁民の中間に位置する。本村がバング ウェウル湖南東岸にある人びとはビサ, 南西岸に ある人びとはカベンデ，と呼ばれる（図 3 )。彼ら は，民族集団全体として（ｉ），（ii ）型のよう に分類することはできない。

漁䈍キャンプにおける聞き込みによれば，（ｉ） 型に分類されるグンボ，ムクルの漁民は，本村周 辺におけるキャッサバ栽培のための作業が，毎年 11〜12月から始まる。6〜9月は野焼きとその後 の農閉期にあたるので, 漁撈期間は $4 \sim 11$ 月初旬 に限定される，という。Cunnison（前掲，pp. 16 -18）は，ルアプラ川下流地域に居住する民族の 生活を述べる中で，彼らは $12 〜 1$ 月に塚を築いて キャッサバを植え付ける，という。1 年目の塚に はカボチャ, トウモロコシ, 落花生などの作物も 栽培し， 5 月までにそれらを収穫する。 2 年目か ら，成長が進んだキャッサバを利用し始め，それ 
は 4 年目まで続りられる。焼畑を用いた雑穀栽培 であるチテメネ農耕にたずさわるのは少数の農民 に限られ，彼らは川やスワンプに出漁するかわり に収穫物であるシコクビエとのバーター取引によ って魚を手に入れる，という。筆者は（ｉ）型 漁民の本村を訪れていないが，彼らの本村におけ る農耕様式も，ルアプラ河畔の住民と類似したも のである可能性が高い。彼らが，乙の時期にmu$k o m b o$ 漁を選択して活動する要因としては，以 下の諸点をあげるととができる。

(1) 4 〜 10月は, 雨季にスワンプに拡散したシク リッド科の大型魚類がスワンプに滞留しており, 捕獲が容易である。

(2) この期間にはスワンプの水位が低下する（図 4 ) ので, mukombo 漁の遂行に望ましい状態 になる。水深が深いと, この漁を行なうととが できないからである。

(3) $6 \sim 9$ 月には最高気温が $30^{\circ} \mathrm{Cを}$ 越える日が少 なく, mukombo 漁における頻繁な移動も，漁 民にとって困難な作業ではない。

(4) 彼らは本村からのアプローチが長く，小さな カヌーを用いてスワンプに入るので，一度に多 量の漁具（漁網など）を搬入することが困難で ある。定置網による営利的漁撈では多数の漁網 が必要とされるが, mukombo 漁は，1 枚の漁 網（kacaala）と吒き棒 (akatole) 1 本で行 なうことができる。また，kacaalaには沈子が 付けられていないので, 沈子付きの漁網より軽 量であり，漁民の移動を一層容易にする。 以上の理由から，（i ）型漁民は，まだ水位 の高い 4〜 5月にはmalalikishya 漁を行なうが, 水位がさがってくると, 漁法を mukombo 漁に切 り換える，と考えることができる。

（ ii ）型の漁筋活動を行なう漁民，たとえば力 ソマ島の住民は村の周囲に十分な広さの土地が得 られず，本村から数 $\mathrm{km}$ 離れた地点に出作り集落 ( $a$ malimino)を作って周囲の土地を耕す。 $8 \sim 10$ 月 はスワンプの水位む低下し，彼らは干上った土地 に塚を築いて, キャッサバ, サッマイモなどを植 え付ける。農耕には適さない八ビタットに居住し ながらも, 彼らは独特の方式で農耕を営んでいる。
したがって，彼らは農耕期間の前後である $4 \sim 7$ 月と10〜 1 月に漁撈キャンプに出かけ，漁を行な うことができる。つまり，スワンプ島民は，農耕， 漁撈活動のために何力月間かずつ本村を離れるこ とになる。次に, 彼らによって定置の刺網漁が選 択される要因を列挙してみる。

(1) 4 〜 月は，まだスワンプの水位が高いが， malalikishya 漁を行なうことができる。

(2) 10〜12月は, モルミルス科魚類が水位の低下 したスワンプに集中するので, ukusebeshya 漁 によって大量に捕獲するととができる。Jackson （前掲，p.33）によれば，なかでもMarcusenius macrolepidotus (mintesa) は, 産卵のため 年周期的に移動することで知られており（BellCross, 1960), 雨季の 3〜 4 力月後に移動する, という。Brelsford（前掲, p 61）は, この魚が 移動中に，筌漁によって大量に捕獲される，と 述べているが, Jackson はまた，乙の移動は乾 季の進行に伴って水中の酸素分圧が低下する現 象から魚が逃れるために起こるのであろう，と 推測している。

(3) 10〜12月は， 6〜 7 月より気候が温暖化し, ukusebeshya 漁のため夜間に活動することが容 易になる。

(4) $12 ， 1$ 月は降雨が頻繁で, ukusebeshya 漁を 続けることは困難になるが, 引き続いて malalikishya 漁に切り換えることができる。

(5) 彼らは漁場へのアプローチが短く, 本村から キャンプまで漁具を容易に搬入できる。

以上の理由から，（ii ）型漁民の漁撈期間は （ｉ）型漁民とわずかに重なる4～7月，10～ 1 月であり, malalikishya 漁とukusebeshya漁を 組み合わせて行なうのである。

湖畔の町，サンフィヤやチャバなどに近接した 地域に本村を持つ人びとは，食料，燃料や工業製 品などの生活物資を容易に手に入れて利用するて とができるので, 漁掞活動にも幅広い選択が可能 である。彼らは，各ユニットの事情によって, $m$ ukombo 漁やmalalikishya 漁以外飞も, ubwam$b a$ 漁, mukwao 漁などを営利漁法として選択す るととができる。本村周辺ではトウモロコシ，キ 
ヤッサバなどを栽培するが，大規模な焼畑農耕は 行なわない。彼らは，（ｉ）型漁民のように本 村がスワンプから離れておらず，（ ii )型漁民の ように農耕期間による制約も少なくて，スワンプ と本村の間を頻繁に往復することができる。

これら複数の民族集団によるスワンプ利用をま とめると, 漁民は, 本村周辺における農耕その他 の生業活動と, スワンプまでの距離に規定されて 特定の漁法を選択し, 漁掞活動に従事するのであ る。漁法ごとに漁期, 漁場を異にし, 漁獲内容も 異なる。その結果, 他漁法を行なう漁民との間に は，同一資源をめぐる競合が生じないことになる。 前稿（前掲，p 87）にあ指摘したように，スワン プ利用をめぐり，漁民間には「すみわり現象」が 成立している。

前述のように，スワンプの水位は季節による変 動が激しく, 通年的に冠水しない土地はごく限ら れる。したがって，人びとはスワンプに定住する ことができず，期間を区切って活動せざるを得な い。乙れは，スワンプ島の住民である，ウンガに さえもあてはまることであった。漁民の活動期間 は限られるが, 魚類も季節的にスワンプ内を移動 するので, 漁期と漁法を適切に選択すれば, 効率 よく漁獲をあげることができる。このように，ス ワンプ漁民は農耕, 漁䈍という 2 種の異なる生業 活動を時限的に行なうととにより，それらを 1 年 の生活暦に組み込んでいる。

\section{VII 結 論}

前章で論じたように，漁撈様式が民族集団ごと にパターン化された主要因としては，本村からス ワンプまでのアプローチの長さと，農作業による 制約をあげることができる。

アプローチが短い民族集団（ウンガ）の漁民は， 漁具などの運搬には問題が生じないが，キャッサ バ栽培のためにスワンプ内で行なう耕作活動によ って，漁撈期間が限定される。10月から12月にか けてはモルミルス科魚類の活動性が増し, ukusebeshya 漁によって集中的に捕獲するてとができ る。
アプローチが長い民族集団（グンボ，ムクル） の漁民は，定置網漁で収益をあげるのに十分な漁 具を，スワンプに搬入することが困難である。6 〜9月は本村の周辺でほとんど耕作活動が行なわ れないので，人びとはスワンプで漁撈に従事する ことができる。この時期は, シクリッド科魚類が スワンプ域に集中し, 水位む低下するので, 彼ら はmukombo 漁を選択する。

スワンプは漁民の本村から距離的に隔たり，し かむ人間の居住環境として決して快適とはいえな い。それにもかかわらず，彼らはスワンプ漁掞に 強く引かれ，スワンプで活動してきた。最後に， ての地域の人びとが漁を行なう動機を探り，スワ ンプ漁撈を住民生活の中に位置づけてみたい。

従来は，スワンプは農耕に適さないマージナル なハビタットであり，そこでは自然に強く依存し た漁掞を主生業とし, 周辺の農耕民からは軽茂さ れながら彼らと共生関係を保持しつつ生活する集 団がいる（掛谷ら，1983,p.44）とされてきた。 すでに安渓 (1984,pp. 337-421，1986,pp. 249 -277）は, ザイール川沿いに住むソンゴーラ族に みられる, バーター市を介した農耕民と漁撈民の 共生関係について詳細に報告し，異なる生活空間 を利用する農耕民と非農耕民の間には, 食物のバ 一ターに支えられた共生的関係が普遍的に存在す る，と論じている。しかし，バングウェウル・ス ワンプの漁民は, 農耕を重要な生活基盤としなが らも漁掞を行ない，スワンプに棲息する魚類を利 用していることが明らかになった。

スワンプ全域に大型船のような交通, 運搬手段 を導入することは困難で, 漁船, 漁具などに十分 な投資ができない。したがって，現在のととろバ ングウェウル・スワンプでは, 都市を市場にして 最大限に利潤を追求する漁業は存在していないが, しかし漁民は漁獲の売却により, ザンビアの他地 域の農耕民に比べて，多額の現金を手に入れるこ とができる。現金獲得への大きな期待から，スワ ンプ漁民が，本稿で述べたような集約的な形で活 動することは明らかである。乙れが，人びとの間 に共生関係が成立するてとを妨げている大きな要 因であろう。また，狩編を頻繁に行なわず，本村 
にはイヌ、ニワトリ以外の家畜をほとんど所有し ない彼らにとって, 魚肉のもつ魅力は何ものにも 替えがたいであろう。漁民が妻子を伴って漁掞キ ャンプで生活しようとするととも，その表われと 考えられる。つまり，スワンプ漁筋は，男性だけ が行なう都市や鉱山への出稼ぎ労働とは性格が異 なる。漁撈活動そのあのは男性中心に行なわれる が，スワンプ生活は家族ぐるみで行なわれるので ある。スワンプ周辺の住民生活の中では, 農耕あ 漁撈も不可欠な要素になっている，ということが できよう。

\section{謝 辞}

本稿のもとになった現地調査は, 昭和 58,60 年 度の文部省科学研究費補助金 (海外学術調査, 研 究代表者, 掛谷誠) の交付を得て行なわれた。

調査にあたっては, ザンビア大学アフリカ研究 所から共同研究員の資格を与えられた。同研究所 においては, S.P.C. Moyo所長, P.B. Hayward 博士をはじめとする多くの方々から御支援を頂いた。 また, ザンビア大学生物学科のP.S.M. Phiri氏に は，スワンプで採集した植物種の同定をお引き受 け頂いた。てれらの方々に厚く感謝したい。

サンフィヤにおいては, バングウェウル水産局 の調査官J.J. Chaika 氏, サンフィヤ県知事B. Lubilo 氏をはじめ多くの方々に便宜を計って頂いた。 そして, 筆者がスワンプで調査中に出会い, とも に暮した漁民の皆さんは，筆者が漁撈キャンプや カソマ島に滞在することを快くお許しになり，根 気よくつき合ってくださった。彼らの暖かい協力 がなければ，スワンプで無事に調査を行なうこと はできなかっただろう。厚く御礼申し上げる。

また, 調査隊の研究代表者, 筑波大学の掛谷誠 博士をはじめ, 隊員の皆さんの御理解之御協力に 深く感謝する。中でも, 京大アフリカ地域研究セ ンターの市川光雄博士は, 昭和58年度の調査隊で は筆者ととあにスワンプ漁撈を分担され，スワン プ域において多くの御教示を賜った。

同センターの田中二郎博士からは, 本稿の草稿 段階でまことに懇切な御指導を賜った。深謝する 次第である。

\section{参考文献}

安渓遊地, 1982.「ザイール川とタンガニイカ湖漁㩐 民の魚類認知の体系」『アフリカ研究」21:1-56. ，1984. 「“原始貨幣》としての魚一中央了 フリカ・ソンゴーラ族の物々交換市—」伊谷・米 山編『アフリカ文化の研究」：337-421. アカデミ 了出版会.

一，1986。「物々交換が結ぶ森の民と川の民一 ーソンゴーラの生活」伊谷・田中編『自然社会の人 類学」:249-277. アカデミア出版会.

Bell-Cross, G., 1960. Observations on the movement of fish in a fishladder in Northern Rhodesia. Proc. 4th C.C.T.A./C.S.A. Hydrobiology \& Inland fish. Symposium.

Brelsford, W.V., 1944. The Bangweulu Channel. Journal of Rhodes-Livingstone Institute, No.1:52-56.

- 1946. Fishermen of the Bangweulu Swamps, - A study of the Fishing Activities of the Unga Tribe. Rhodes-Livingstone papers, No.12, Manchester University Press.

Central Statistical Office., 1974. Census of Population and Housing, 1969. Final Report vol.IV.(d3) Samfya District. Government Printer, Lusaka. , 1977. Fisheries Statistics, 1971. Natural Waters vol.1. Government Printer, Lusaka.

Cunnison, I., 1959. The Luapula Peoples of Northern Rhodesia-Customs and History in Tribal Politics. Manchester University Press.

Evans, D.W., 1983. Lake Bangweulu,- a stu$d y$ of the complex and fishery., Fisheries Service, Zambia.

Everett, G.V., 1974. An Analysis of the 1970 Commercial Fish Catch in three Areas of the Kafue Floodplain. African Journal of Tropical Hydrobiology and Fisheries. vol.3(2):147-159.

端 信行, 1968.「トングエ地方における湖岸集落の 形成とダガー漁業」今西・梅棹編『アフリカ社会の 研究』: 327-338. 西村書店.

原子令三，1977。「ムブティピグミ一の生態人類学的 研究」, 伊谷・原子編『人類の自然誌』: 29-95, 雄山閣.

市川光雄, 1982.『森の狩猟民一ムブティ・ピグミ 一の生活』, 人文畫院.

Ichikawa, M., 1985. A Comparison of Fishing Strategies in the Bangweulu Swamps. African Study Monographs, Supplementary Issue 4:25-48.

Imai, I., 1985. Fishing Life in the Bangweulu Swamps-A Socio-ecological Study of the Swamp Fishermen in Zambia. African Study Monographs, Supplementary Issue 4:49-88. 
Jackson, P.B.N., 1961. The Fishes of Northern Rhodesia.-A Check List of Indigenous Species. Government Printer, Lusaka.

掛谷 誠, 1974. 「トングウェ族の生計維持機構生活環境, 生業, 食生活」『季刊人類学』5-3:3-90. 講談社.

掛谷 誠, 市川光雄, 1983 .「ザンビアにおける生態 人類学研究上の諸問題—予備調査報告—」『ア フリカ研究』23:38-49.

Kakeya, M., Sugiyama, Y., 1985. Citemene, Finger Millet and Bemba Culture: A Socioecological Study of Slash -and-burn Cultivation in Northeastern Zambia. African Study Monographs, Supplementary Issue 4:1-24.

Kay, G., 1962. A Population Map $(1: 500,000)$ of the Luapula-Bangweulu Region of Northern Rhodesia with Notes on the Population. Rhodes-Livingstone Communication 26.

Rhodes-Livingstone Institute, Lusaka.

Longworthy, H.W., 1971. Language and Tribes. Davies,D.H. (ed.) Zambia in Maps.

University of London Press.

Meteorological Department, 1971. Climatological Summaries for Zambia. Periods ending December 1970. Government Printer, Lusaka.

Mortimer, M.A.E., 1965. Ch.VII. Fishing Gear, Methods and Craft. Mortimer,M.A.E. (ed.) The Fish and Fisheries of Zambia:33-43. Falcon Press, Ndola.

Mushindo, P.B., 1977. AShort History of the Bemba. National Educational Company of Zambia.

Sato, S., 1980. Pastoral Movements and the Subsistence Unit of the Rendille of Northen Kenya : with Special Reference to Camel Ecology. Senri Ethnological Studies, 6:1-78. National Museum of Ethnology, Osaka.

Tait, C.C., 1965. Bangweulu. Mortimer, M. A.E. (ed.) The Fish and Fisheries of Zambia $: 69-75$.

田中二郎, 1971。 アブッシュマン一生態人類学的研 究』思索社.

Tanaka, J., 1980. The San: Hunter-Gatherers of the Kalahari. University of Tokyo Press. 丹野 正, 1977.「ムブティ族ネット・ハンターの狩 铍活動とバンドの構成」, 伊谷・原子編「人類の自 然誌』:97-134. 雄山閣. 